\title{
A Revision of the Seed Impressions of the British Coal Measures.
}

\begin{abstract}
E. A. NEWELL ARBER, M.A., Sc.D., F.L.S., Trinity College, Cambridge; University Demonstrator in Palaeobotany.
\end{abstract}

With Plates VI-VIII and eight Figures in the Text.

$\mathrm{T}$ HE occurrence of a variety of impressions or casts of seed-like bodies in the British Coal Measures has been known since the days of John Woodward ${ }^{1}$ (I729), yet at the present time there is probably no set of Coal Measure fossils which stands in greater need of systematic revision than these. The most recent list of such objects, published by Dr. Kidston ${ }^{2}$ in 1894 , includes only five genera with nineteen species from the whole of the British Coal Measures. Of these genera one, Carpolithus, containing nearly one-third of the total number of species, is nondescript, and amounts to little more than the word 'seed'. It is a useful term under certain circumstances, but should be regarded only as a temporary expedient. There is little doubt, I imagine, that the Coal Measure seeds which have been referred to this genus are of several fundamentally distinct types.

When determining Coal Measure fossils, one frequently finds that, while there is no hesitation as to the specific assignment of a particular seed, there is often doubt as to whether such and such a species really belongs to the genus to which it has commonly been assigned, and especially whether it possesses any real morphological affinity to the other species contained therein. In my own case, however, I have found it necessary to defer any opinion on such questions until an opportunity should occur for re-investigating the grouping of Coal Measure seeds in general.

In attempting this difficult task here, I am well aware that the principles on which a nomenclature should be founded are to some extent matters of opinion, and that in some cases differences of opinion are likely to arise as to matters of fact. The botanical interpretation of the features exhibited by a particular impression is sometimes by no means an easy

$$
1 \text { Woodward (1729), p. 53. } 2 \text { Kidston ('94). }
$$

[A.nnals of Botany, Vol. XXVIII. No. CIX. January, 1914.] 
task, yet it is on these grounds that a classification should be based. In my opinion one of the most fundamental distinctions among Coal Measure seeds should be founded on the symmetry. We know from the study of petrified specimens that most of these fossils belong to two distinct types, the Radiosperms and the Platysperms, as $\mathrm{F}$. W. Oliver ${ }^{1}$ pointed out in 1903 . The former are symmetrical in more than two planes, the latter in only two or in a single plane. At the same time a classification based solely on symmetry is not ideal. Certain seeds, such as Trigonocarpus Parkinsoni, are radiospermic from one point of view, and platyspermic from another. Although the number of such cases is few at present, an intermediate class may have to be recognized eventually. ${ }^{2}$ The main difficulty as regards the recognition of the type of symmetry among impressions arises, of course, from the compression which many seeds have undergone before or during fossilization. From an isolated example it may be sometimes impossible to determine whether the seed in question is radiospermic or platyspermic, especially if it be a new or rare type. In such circumstances it is best referred to the genus Carpolithus. But it will be found that, when a considerable number of specimens of the same seed from different localities are compared, it is usually fairly easy to settle this question, at least provisionally. It is extraordinary how, in many cases, both radiospermic and platyspermic seeds have escaped compression, or have been flattened only to a slight degree. Even such seeds as Cordaicarpus, the nucellus of which in the natural state was probably narrowly elliptical in transverse section, and which, one imagines, would only require comparatively slight pressure perpendicular to the major axis to become quite flattened, have often escaped with but little distortion of the original form.

At the present time there is considerable confusion as to the limits of the generic terms in common use. This arises partly because the subject has not undergone revision for more than half a century, and partly because of the extremely unfortunate practice of including impressions in genera founded on structure material, or vice versa, without at the same time affording satisfactory proof of the correlation of the impression with the petrifaction or vice versa. This is quite unjustifiable. It was perhaps less glaring a decade ago, when the diversity in anatomical structure to be met with in Palaeozoic seeds had not been so fully recognized. New types of seed structure should receive temporary names as they are discovered, until the time arrives when a definite proof can be afforded of their generic correlation with impressions, the names of which have been in existence for a century. Further, a diagnosis of a genus such as Cardiocarpus should take into account the external form of the seed in addition to the details of its anatomical structure, for this name has been in use for impressions since 1828 .

1 Oliver ('03), p. 453 .

${ }^{2}$ Oliver and Salisbury ('11), p. 44 . 
I do not propose in the present instance to deal at all with structure specimens, still less with the difficult correlation of such petrifactions with impressions. My present task is merely to sort out and to reclassify the impressions.

From the point of view of the study of impressions the testa and its characters are all important. I assume that very few radiospermic seeds, as Oliver ${ }^{1}$ has pointed out, and as experience with impressions confirms, have a testa differentiated into a fleshy outer sarcotesta and a hard inner sclerotesta. The converse, however, does not hold good. Some Platysperms, such as Cardiocarpus, as here restricted, Cormuspermum and Cordaicarpus, show no signs of a differentiated testa. In others, however, such as Samaropsis and Samarospermum, the differentiation of the testa is very obvious. In the latter type, it is convenient to speak of the central portion of the seed as the 'nucule', an ancient term implying the nucellus surrounded by the hard sclerotesta. The soft sarcotesta as viewed in impressions is nearly always flattened over the nucule, and the rim of sarcotesta surrounding the nucule is conveniently described as the 'wing'.

I regret that it has been found necessary here to institute a large number of new generic terms, partly because a considerable number of new species are described for the first time, but more so because there is a very great variety among seed impressions, - a variety which must find adequate expression unless these fossils are to remain bunched indiscriminately into such nondescript genera as Carpolithus. On the other hand, I am well aware that it may eventually be found that more than one generic type has here been included in a single genus, especially in the case of the new genus Radiospermum. But this is a defect which only time and further evidence can remedy. The total number of genera here recognized is 14 , and 37 species are described. The latter part of the paper is devoted to an attempt to define these genera and species more exactly than has hitherto been possible. Of the I4 genera here recognized, 9 are new, the remainder have been already employed for continental specimens. On the other hand, of Dr. Kidston's 18 species, all but 4 are recognized, though the great majority of them are referred to other genera. Ten new species are described here, and twenty-seven others are recognized which have either been previously recorded by Dr. Kidston, or have been unknown from Britain though known from the Continent. A figure of every British species is included.

It is hardly necessary to point out perhaps that the detached seed impressions, here under consideration, belong to at least two very diverse groups, the Pteridospermeae and the Cordaitales. At present we are unable to discriminate between the seeds of these groups. All that we can

1 Oliver ('03), p. 453.

G 2 
say is that some species of Samaropsis and Cordaicarpus belong to the Cordaitales, and that, of the other genera, some or all species may belong to the Pteridosperms. The platyspermic seeds appear to be the more varied type, nearly double the number of genera and species of these seeds, as compared with the Radiosperms, being recognized here.

I will begin with Trigonocarpus, the best known Coal Measure seed, both as an impression and as a petrifaction. This is a happy case in which it has been possible to correlate both types of preservation very exactly. Though Trigonocarpus Parkinsoni, Brongn., stands secure, the other types which have been referred to this genus have caused trouble and confusion, and may continue to do so for some time yet.

\section{Trigonocarpus, Brongn.}

T. Parkinsoni, Brongn. This species has been so thoroughly investigated by Scott and Maslen ${ }^{1}$ that a bare mention of it here is all that is necessary. As an impression this seed occurs in three states of preservation.

Forma a. This shows the external surface of the sarcotesta, the true outer surface of the seed. It is the ancient Carpolithes alata of Lindley and Hutton, and is one of the most unmistakable of Coal Measure fossils.

Forma $\beta$ (P1. VI, Fig. 2) shows only the sclerotesta and micropyle. In impressions the latter is frequently covered up by the rocky matrix, and in this condition it is sometimes difficult to recognize this state. The surface of the sclerotesta, in my experience, is smooth, as in Fig. 2, and a difficulty also arises here, as Scott and Maslen have pointed out, ${ }^{2}$ for in the petrified specimens the outer surface of the sclerotesta possesses twelve longitudinal ridges ${ }^{3}$ of unequal prominence. I am unable to throw any light on this matter. This state was originally described as Rhabdocarpus Bochschianus by Berger. ${ }^{4}$

Forma $\gamma$ (Pl. VI, Figs. 3-5), the well-known, tri-ridged casts of the nucellus or seed cavity. This is the state to which both the specific and generic names were first applied in 1828 . So far as I am aware these casts never show any sign of splitting at the pointed end, or of a definite foramen at the rounded basal end. The latter is sometimes quite smooth (Fig. 4, lower seed), or sometimes there is a small, projecting, oval umbilicus, as in Figs. 4 (upper seed) and 5 , which Scott and Maslen ${ }^{5}$ regard as probably indicating ' the edge of the tracheal disc from which the free nucellus sprang'. I have, however, never seen any definite foramen disclosing an inner cast, and this, as we shall see, is important in relation to some other casts, which have so far been referred to the same genus.

1 Scott and Maslen ('07), p. $9^{6 .}$

4 Berger ('48), p. 2 I, Pl. I, Figs. I3, I 4.
2 Ibid., p. I 30. 3 Ibid., p. 106.

${ }^{5}$ Scott and Maslen ('07), p. 128. 
We have next to inquire whether any other species of this genus are known from the British Coal Measures as impressions. After a careful study of the subject, I have arrived at the somewhat startling conclusion that there are only three other species known from this country, and none of them so completely as T. Parkinsoni, Brongn. These are :

Trigonocarpus Moyseyi, sp. nova. Forma a.

Trigonocarpus Dawesi, L. \& H. Forma $\gamma$.

Trigonocarpus clavatus (Sternb.). Formae $\alpha$ and $\beta$.

Trigonocarpus Moyseyi, sp. nova (Pl. VI, Fig. I). I originally figured ${ }^{1}$ this fine specimen in Dr. Moysey's collection as Trigonocarpus sp., with the suggestion that perhaps the so-called T. Noeggerathi of Sternberg might be the forma $\gamma$ of this seed. At that time I was under the impression that the above species was a state of a true Trigonocarpus. A more careful study of the subject, however, has led me to remove T. Noeggerathi, Sternb., from the Platysperms, at least provisionally, for the reasons stated below (p. 86). I now regard Dr. Moysey's specimen as the type of a new species, which I name T. Moyseyi, sp. nova, in honour of one who has done so much for the palaeontological investigation of the Nottingham coalfield.

T. Moyseyi differs from T.Parkinsoni chiefly in size and shape, as will be realized if Pl. VI, Fig. I be compared with the specimen figured by Scott and Maslen on Pl. XII, Fig. I 7 of their paper. Both figures are magnified equally. T. Moyseyi is much broader in proportion to its length, and has a shorter micropyle. The formae $\beta$ and $\gamma$ of this seed are unknown.

Trigonocarpus Darvesi, L. and H. (Pl, VI, Fig, 8). This seed is only known as forma $\gamma$ casts, which correspond almost exactly to T. Parkinsoni, forma $\gamma$ except in size. It is twice as large as the latter. It is a rare type.

Trigonocarpus clavatus (Sternb.) (Text-fig. I, p. 95). The obscure and rare types, the Carpolites clavatus and $C$. langenarius of Sternberg, which Geinitz and others have referred to Rhabdocarpus, are in my opinion probably a small Trigonocarpus, formae $a$ and $\beta$. The general shape of the seed, the micropyle, and the fleshy sarcotesta support this conclusion. The fine longitudinal striation of the testa, on which stress has been laid as an indication of generic affinity, is in reality common to several genera of Palaeozoic seeds. This is the smallest British example of the genus, and may possibly be only an immature condition of another species, though this is by no means certainly the case.

These are the only British representatives of the genus which I am inclined to recognize. There are, however, several other species, usually placed in this genus, which may be briefly discussed. A knowledge of the forma $\gamma$ casts of Trigonocarpus Parkinsoni has had a very profound influence on the nomenclature of other Palaeozoic seeds. Any egg-shaped cast,

${ }^{1}$ Arber ('10), p. I50, Pl. XVIII, Fig. I, Pl. XIX, Fig. 3, and Arber ('09), p. $4^{2}$. 
showing three prominent ribs, has sometimes been referred to the genus Trigonocarpus without hesitation. For some years past I have had a strong suspicion that a cause of error may have arisen here. I am now convinced that several tri-ridged casts represent, not forma $\gamma$ casts of Trigonocarpus, but the external surfaces of radiospermic seeds, though it will no doubt be a matter of dispute for some time yet as to whether I am correct or not in this conclusion.

The most difficult case in this connexion is the seed which I here term-

\section{Schizospermum Noeggevathi, Sternb.}

This is a seed (Pl. VIII, Figs. 48-50) similar in some respects to the forma $\gamma$ casts of $T$. Parkinsoni, and of nearly equal abundance in the Coal Measures, which was originally described by Sternberg ${ }^{1}$ in 1826 as Palmacites Noeggerathi, and regarded by him as the seed of a palm. Brongniart ${ }^{2}$ in I 828 transferred this fossil to his Trigonocarpum, and this view has been adopted by Berger ${ }^{3}$ and Zeiller, ${ }^{4}$ who have since figured specimens of the same seed. So far the synonymy has remained pure, and so far as one can judge all the specimens figured are identical. Of the two specimens more recently figured by Dr. Kidston, that from Radstock ${ }^{5}$ may be Sternberg's plant, though the figure does not show the characteristic features of this species. I am convinced, however, that the figure of the Lancashire specimen ${ }^{6}$ represents Trigonocarpus Dawesi, L. and $\mathrm{H}$.

There are a large number of specimens of Sternberg's species in the Sedgwick Museum, from the Middle and Upper Coal Measures of many localities. A careful examination of these shows that they possess two well-marked features, which I have never observed in T. Parkinsoni, forma $\gamma$. At one end of the cast, the outer coat of the seed splits into three valves (Pl. VIII, Fig. 49). This is almost universally the case, and is not due to compression. At the other end of the seed, there is a foramen, a fairly large round or oval hole, disclosing another cast within (Pl. VIII, Fig. 50). These facts are exactly as depicted in Zeiller's figures (see above). From the apex of each of the three valves a fairly well-marked longitudinal ridge proceeds nearly to the base, hence the attribution to Trigonocarpus. These three ridges alternate with the splitting lines, which are themselves ridges, so that there are six ridges in all.

It appears to me to be quite impossible to believe that these casts are casts of the internal surface of the sclerotesta of a Trigonocarpus. If they are, how are the valves explained? They are certainly not accidental nor confined to a few specimens. What is the foramen, and the cast internal to

1 Sternberg ('20), Heft iv, p. xxxv, Pl. LV, Figs. 6, 7 .

2 Brongniart ('28), p. I37.

3 Berger ('48), pp. 15, 18, Pl. I, Figs. I, 2.

4 Zeiller ('86), p. 649, Pl. XCIV, Figs. 8-I I ; ('00), p. 223 , Fig. I 49.

${ }^{5}$ Kidston ('88), p. 403, Pl. XXIII, Fig. 3. ${ }_{6}^{6}$ Ibid. ('89), p. 4I 4, Pl. II, Fig. 4. 
the valves? It seems to me to be much more likely that we are dealing here with the true external surface of a radiospermic seed. In a very large number of examples no trace of any fleshy sarcotesta is to be seen, and therefore this is presumably not a forma $\beta$ cast. My view is that it is the external surface of a seed, the integument of which when ripe opened by three valves exposing the nucellus at the apex of the seed; that the foramen represents the point of attachment of the stalk, and that the cast. seen within is a cast of the nucellus. I therefore propose to transfer this species to the Radiosperms, as a member of a new genus Schizospermum, namely S. Noeggerathi (Sternb.). The possession of three longitudinal ridges is common to several other Radiosperms, as will be shown here, and the foramen and inner cast are also seen in some of these. Further, in a unique but obscure specimen, at present referred to the new genus Radiospermum as $R$. problematicum (Pl. VII, Fig. 37 ), there is also evidence of splitting at one extremity of the seed. At present, however, it is not known whether this was a natural feature or not.

Radiospermum ovatum (L. and H.) (P1. VII, Fig. 32). There is a large and very rare seed in the Middle Coal Measures of Coalbrookdale and Yorkshire, which was first figured by Lindley and Hutton ${ }^{1}$ as Trigonocarpum ovatum, and by Morris ${ }^{2}$ as Carpolithes zamioides. The cast is cylindrical; there are three well-marked longitudinal ridges, as in many other radiospermic seeds, and a foramen occurs at the base, disclosing an inner cast. It differs from Schizospermum Noeggerathi in the fact that the integument of the seed does not separate into three valves, and also in size and shape. This also I am inclined to regard provisionally as the external surface of a radiospermic seed, and not as a cast of the seed cavity of a $\gamma$ form of Trigonocarpus. It seems to me to fall within the new genus Radiospermum as defined below (p. 92).

\section{Platyspermum, gen. nova., and Rhabdocarpus, Berg.}

This completes the list of British Coal Measure plants which have been referred to the genus Trigonocarpus. We now turn to the platyspermic seeds, and especially to those hitherto referred to the genus $R$ habdocarpus. This name appears to be used in a somewhat loose sense at the present time. ${ }^{3}$ In my opinion it should be reserved for unsymmetrical seeds, similar to Rhabdocarpus tunicatus, Berger, ${ }^{4}$ as the type of the genus, and $R$. subtunicatus, Zeiller. ${ }^{5}$ These seeds are Platysperms, with a large

1 Lindley and Hutton ('31), vol. ii, P1. CXLII a.

2 Morris ('40), p. 489, Pl. XXXVIII, Fig. 4.

3 Berger, the founder of the genus, himself included several different types under this name. His paper is, however, merely a student's thesis for a degree, and it is doubtful whether such dissertations should be recognized.

4 Berger ('48), p. 20, Pl. I, Fig. 8 (right side).

5 Zeiller ('92), p. 93, Pl. XV, Fig. II ; the R. tunicatus of Grand' Eury ('77), pp. 206, $3^{\mathrm{I}} 3$, Pl. XV, Fig. I2 ; and Renault ('90), p. 638, Pl. LXXII, Fig. I 9. 
unsymmetrical nucule, enclosed in a large unsymmetrical wing or sarcotesta, the seed being apparently symmetrical only in one plane. The fact that the sarcotesta is ornamented with close, parallel, longitudinal striae is probably of no systematic importance, for the same feature occurs in the case of other platyspermic and also among radiospermic seeds. My conclusion is that this Stephanian and Permian type of seed has been hitherto unknown from the British Coal Measures, and that all the British species so far referred to it are symmetrical in two planes, and are not obviously winged. I therefore propose to transfer them to a new genus, Platyspermum. P. sulcatum, Sternb. (Pl.VI, Fig. I I), and P.elongatum, Kidst. (P1.VI, Fig. I2), belong here, and so does the true $P$. multistriatum of Sternberg. The specimen from the Radstock coalfield, figured by Dr. Kidston ${ }^{1}$ under this name (Pl. VI, Fig. 9), I believe to be a new species, and not Sternberg's seed. I have included it here as $P$. Kidstoni, sp. nova, and have also figured what I take to be the true P. multistriatum of Sternberg (Pl. VI, Fig. Io). $P$. Kidstoni appears to me to lie nearer to $P$. sulcatum, Sternb., than to $P$. multistriatum, Sternb., in that the ridges approximate at the base and apex. I, however, only know Dr. Kidston's specimen from the published drawing. Another new species, $P$. rugosum, with coarse ribbing, is also described here (Plate VI, Fig. I3).

While the above species, here referred to the new genus Platyspermum, are in my view morphologically distinct from Rhabdocarpus tunicatus, Berg., and $R$. subtunicatus, Zeill., there is, however, one seed known to me which does appear to be a true member of the latter genus. Two examples of this are figured on Plate VII, Fig. 2I. It is apparently a new species which I propose to call Rhabdocarpus Lillieanus, sp. nova.

The genus Platyspermum is not intended to include all platyspermic seeds of Coal Measure age, but only those which are not winged and in which the testa possesses many close, parallel ribs or striations. There are several other types, among which are :

\section{Cornucarpus, gen. nova.}

This new term is proposed for a well-known platyspermic seed, symmetrical in two planes, which is very distinct from all other seeds. It was first described by Lindley and Hutton ${ }^{2}$ in 1833 as Cardiocarpon acutum (Pl. VI, Fig. I4, and Text-fig. 2, p. 97). There is considerable evidence for believing it to be the seed of Eremopteris artemisiaefolia, Sternb., but it has not yet been possible to demonstrate actual continuity between this seed and the fertile fronds of that species. Some years ago Dr. Kidston showed me prepared specimens of this seed rendered transparent, so that the pollen

1 Kidston ('88), p. 404, Pl. XXIII, Fig. 4.

${ }^{2}$ Lindley and Hutton ('31), vol. i, p. 209, Pl. LXXVI. 
chamber could be seen, and there is thus no doubt as to the seed nature of this fossil.

Cornucarpum acutum (L. and H.) is easily distinguished by the more or less triangular shape and the broad apex, with a fairly long horn at each corner. There is also a median ridge. It is thus quite distinct from Cardiocarpus as here defined.

\section{Cardiocarpus, Brongn.}

This name was first instituted by Brongniart ${ }^{1}$ in 1828 for seeds with the following characters: 'fruits comprimés, lenticulaires, cordiformes ou réniformes, terminés par une pointe peu aiguë.'- In recent years there has been some difference of opinion as to whether this genus should be made to include winged seeds. Brongniart's diagnosis says nothing about wings. I am inclined to reserve it for those seeds which apparently did not possess a broad sarcotesta, but in which the testa was heart-shaped or reniform. The following are the British species: Cardiocarpus congruens, ${ }^{2}$ Grand' Eury (Text-fig. 3, p. 97), and C. Gutbieri, Gein. (Pl. VI, Fig. I5). The species referred to this genus by Artis as C. marginatus (Pl. VIII, Fig. 46) is still a type of very uncertain affinities. It may be a radiospermic seed. It must also be remembered that the nucule of badly preserved Samaropsis seeds, in which the wing is not preserved, may simulate Cardiocarpus. In some species of Cardiocarpus there appears to be a slight rim or wing, but I am inclined to think that this is wholly due to the effects of pressure.

\section{Samaropsis, Goepp.}

The genus Samaropsis, Goepp., is maintained here as used by continental authorities in more recent years, though in a slightly restricted sense. In these seeds there is a distinct nucule in the centre, surrounded by a broad rim called the wing. The nuctile is heart-shaped or oval, and the whole wing circular, or oval, or heart-shaped. I would restrict this genus to seeds which are not much longer than broad, or broader than long, separating those forms with a very long and narrow wing as a distinct genus Samarospermum. Samaropsis differs from Cardiocarpus in the clear distinction between the nucule and the wing. In other words, in Samaropsis there is a well-developed sarcotesta; little, if any, in Cardiocarpus. The nucule is of course the sclerotesta.

I propose to refer all Platysperms, with a triangular or heart-shaped nucule, surrounded by a more or less circular wing, to Goeppert's genus Samaropsis, founded in 1864. The British species of Samaropsis are S. fluitans, Dawson (Pl. VI, Fig. I8), S. crassa, Lesq. (Text-fig. 4), S.

1 Brongniart ('28), p. 87.

2 This may be the Carpolites corculum or C. contractus of Sternberg (Vers. Darstell. Flora d. Vorwelt, Heft 5-6, p. xl, Heft I, Pl. VII, Figs. 6 and $7,1820-33)$, but Sternberg's figures appear to be too indefinite to permit of any certain correlation. 
emarginata, Berg. (Text-fig. 5), S. Meachemi, Kidst. (Pl. VI, Figs. I6, I 7), and S. subacuta, Grand' Eury (Text-fig. 6).

Samarospermum, gen. nova.

I propose here to restrict the genus Samaropsis to those seeds in which the wing is of nearly equal length and breadth. There is, however, another type, confined until quite recently to the Stephanian and Permian of Europe, and represented by but a few species. This was originally referred by Helmhacker ${ }^{1}$ to Fiedler's ${ }^{2}$ genus Fordania, as $\mathcal{F}$. moravica, Helmh., which was first figured by Geinitz. ${ }^{3}$ It has, however, been pointed out that this fossil does not agree generically with the species of Fordania figured by Fiedler, and thus Zeiller, Renault, and others have more recently referred it to the genus Samaropsis. Zeiller ${ }^{4}$ has refigured Helmhacker's type specimens. It appears, however, to me to be a perfectly distinct type, worthy of generic distinction, and, since the genus Fordania, Fiedler, is unsuitable for its reception, I here propose the new generic name Samarospermum. This species Samarospermum moravicum (Helmh.) (Pl. VI, Figs. I9, 20) has recently been found in the Middle Coal Measures of the Kent coalfield. The chief peculiarity of this genus is the great elongation of the seed, which is very narrow in proportion to its length, and possesses only a small nucule.

The specimens figured by Weiss ${ }^{5}$ in 1879 , under the name Fordania moravica, appear to be specifically distinct from the plant first figured by Geinitz.

\section{Microspermum, gen. nova.}

So far as I am aware, no seed impression has as yet been described from Britain which appears to be only symmetrical in one plane. As far as one can judge, without any knowledge of the anatomy, all the British Platysperms, hitherto described, appear to be symmetrical in two planes. We now come to a small seed, if indeed it be a seed, which has several curious features, and which like Rhabdocarpus Lillieanus, sp. nova (see p. 88), is only symmetrical in a single plane. I have only seen this seed from the Middle Coal Measures of the Nottinghamshire coalfield, and I am indebted to my friend Dr. Moysey for the loan of a fine suite of specimens of it. It is here placed in a new genus Microspermum, as it is quite distinct from any other type of seed known to me.

The seed in question is a small, ovate, or pyriform body from $5^{-10} \mathrm{~mm}$. long, one extremity being rounded, the other contracted acutely. One side is keeled, the other grooved, and a large foramen occurs near the broader end and on the grooved surface.

The British specimens figured on P1. VII, Figs. 22-27 agree fairly well with

1 Helmhacker ('71), p. 8 I.

3 Geinitz, E. ('75), p. I I, Pl. I, Figs. 10, I I.

5 Weiss ('79), p. 36, Pl. III, Figs. I 7 - 9.
2 Fiedler ('57), p. 288.

4 Zeiller ('92), p. 95, Pl, XV, Figs. 9, 10. 
the specimen figured by M. l'Abbé Carpentier ${ }^{1}$ as Carpoiithes ? samaroides, Carp., from the Westphalian of the Nord de France coalfield. The seeds agree in size, though the British specimens are somewhat broader as a rule. M. Carpentier regards his specimens as winged, which is certainly not the case in the English examples, and he does not mention the foramen, which, however, appears to be clearly seen at the broader end of his seed. In his figured example, which only shows one side of the seed, the median groove is much broader than in the specimens figured here. Judging chiefly by his figure, I am, however, inclined for the present to include the British examples in the French species.

The present specimens differ from other seeds in certain important respects, chiefly in their unsymmetrical form. The foramen is, however, a feature met with in certain species of Radiospermum and Schizospermum, where, however, it is terminal. The fossils are solid bodies, and are certainly not foliar in nature. Neither do they appear to be sporangial. They may thus be regarded, at least provisionally, as seminal structures.

\section{Cordaicarpus, Geinitz.}

Next we have the genus Cordaicarpus, Geinitz, 1862 , which in common with Geinitz, ${ }^{2}$ Grand' Eury, ${ }^{3}$ and Zeiller ${ }^{4}$ I am convinced belongs to a member of the Cordaitales. There are several species of impressions, of which Cordaicarpus Cordai, Gein. (PI. VII, Fig. 29), may be regarded as the central type. These are fairly small seeds, oval or orbicular in form, with a smooth testa. Two other well-marked species occur in Britain, C. areolatus (Boul.) (Text-fig. 7) and C.ovoideus, Berg. (Pl. VII, Fig. 30). These are undoubtedly Platysperms. They commonly occur compressed quite flat, in which state there is usually a narrow rim bounding the seed (PI. VII, Fig. 29). They are, however, frequently also found in an almost unflattened condition, and are then elliptical in section (see P1. VII, Fig. 30), resembling Diplotesta, which Bertrand ${ }^{5}$ has shown to be a Cordaitean seed.

\section{Megalospermum, gen. nova.}

To this genus I ascribe a certain very large seed, without any indication of a wing or a nucule, which has been described by Dr. Kidston as Carpolithus Wildii, the testa of which is ornamented by numerous fine and close thread-like striae (Pl. VII, Fig. 28). There may be some doubt at present whether this seed is Radiospermic or Platyspermic, for only a single example is known from Britain. Others, believed to be generically similar,

1 Carpentier ('11), p. 7, Pl. XIV, Fig. 3 ; Ibid. ('10), p. 599.

${ }^{2}$ Geinitz, H. B. ('61), p. I 5 o.

${ }^{4}$ Zeiller ('86), pp. 637, 641.

${ }^{3}$ Grand' Eury ('77), p. 233, Pls. XXV, XXVI, Fig. 9.

5 Bertrand ('11). 
have been described on the Continent, and these appear to be undoubtedly Platyspermic.

Certain other species of this genus have been included by Grand' Eury in the genus Pachytesta, Brongn., a structure genus. At present, however, the identity of Megalospermum and Pachytesta has not been proved, and I agree with Dr. Kidston that, under these circumstances, the impressions should not be placed in the structure genus. This type of seed impression is, however, very distinct, and is worthy of generic separation and removal from the nondescript genus Carpolithus. It is very rare in the Westphalian rocks of England, being more frequent on higher horizons on the Continent.

The radiospermic seeds recorded from the Coal Measures are fewer than the platyspermic types.

\section{Radiospermum, gen. nova.}

This name is proposed to include all the British subcylindrical seeds at present known, except Schizospermum and Neurospermum, the latter being distinguished by the close ribbing or striation of the testa. In Radiospermum, a few distant ribs and discontinuous, small, longitudinal striae may occur, or the testa may be without either type of ornament. Radiospermum includes the small seeds which, when the structure is preserved, are known as Lagenostoma, Physostoma, and Conostoma. ${ }^{1}$ It is however rarely, if ever, possible to recognize the distinguishing characters of these three genera in such minute seeds, when preserved as impressions. Such impressions are best grouped together under Radiospermum perpusillum, Lesq. (Pl. VII, Fig. 3I). In some cases these seeds occur in cupules. ${ }^{2}$ Cupules are also known in the case of $R$. Sinclairi (Arber) ${ }^{3}$ (Pl. VII, Figs. 33,34$)$, but in none of the other species at present. The $R$. perpusillum of Lesquereux may be identical with the earlier published Carpolithes ellipticus of Sternberg, but the figure given of the latter is so indefinite that this name is best ignored.

Two other species, $R$. inflatum, Lesq. (Text-fig. 8), R. Kidstoni (Arber) ${ }^{4}$ (Pl. VII, Figs. 35, 36), have already been recorded, and four new species, $R$. problematicum, sp. nova (Pl. VII, Fig. 37 ), $R$. grande, sp. nova (PI. VIII, Figs. 44, 45), R. ornatum, R. elongatum, are added here. R.grande approximates to the Carpolithes insignis of Karl Feistmantel, ${ }^{5}$ a species which Dr. Kidston ${ }^{6}$ has already doubtfully recorded from the Upper Coal Measures. The British examples are, however, much smaller, and, I think, specifically distinct. Another new seed, R.ornatum (Pl. VII, Figs. 38-4I), is a very distinct type, triangular in section with twelve longitudinal ribs,

1 Cf. Oliver and Salisbury ('11), pp. 37-8.

3 Arber ('05).

4 Ibid.

${ }^{5}$ Feistmantel, K. ('81), p. 99, Pl. VII, Figs. 4, 5.
2 Carpentier ('11), Pl. XII.

6 Kidston ('94), p. 25 1. 
and a peculiarly ornamented testa. The fourth new type, $R$. elongatum (P1. VII, Figs. 42, 43), is cylindrical in form, with faintly marked, rather distant ribs.

I have also doubtfully referred to Radiospermum the Carpolithes marginatus of Artis (P1. VIII, Fig. 46), a very obscure and little known type, the testa of which is quite destitute of any characters which can be cited as distinctive. There may be room for difference of opinion as to whether this seed was radiospermic or platyspermic. The few specimens which I have seen are all compressed, but I think it probable that this is due to pressure, and that the seed was originally radiospermic. The narrow marginal rim seen in some examples is probably also a pressure effect.

\section{Neurospermum, gen. nova.}

This type of seed, which is undoubtedly radiospermic, has in two cases been shown by Dr. Kidston ${ }^{1}$ to belong to Medullosas with the Neuropteris type of foliage. The seed of Neuropteris heterophylla, which has not been named by Dr. Kidston, though it has been compared with certain species of Rhabdocarpus, a platyspermic seed, should, I think, be determined, for it more often occurs in the detached state than in continuity with $N$. heterophylla. As it is obviously impossible to apply the name heterophylla to it, I therefore propose to give it the name Neurospermum Kidstoni (Pl. VIII, Fig. 47) and to regard it as the type of a new genus, in which the testa of the oval or subcylindrical seed possesses close, prominent, parallel, longitudinal striae.

The seed of Neuropteris obliqua ${ }^{2}$ has similar characters, but this seed has not yet been recorded in Britain.

\section{Pterospermum, gen. nova.}

There is a single specimen (V. I1 $8_{3}$ ) in the Geological Department of the British Museum (Nat. Hist.) of a most remarkable seed (Pl. VIII, Figs. $5 \mathrm{I}, 52)$, in an ironstone nodule from the Middle Coal Measures of Coseley, South Staffordshire, which is the only example known from this country. The ironstone nodule has been broken into three pieces, each corresponding to the spaces between the giant wings of this seed. The whole can thus be fitted together, and the general form of the seed studied. Although there is no cross-section of the whole nodule, I deduce that the nucellus was probably of very small transverse area, and triangular in form, each angle being produced into a large flap-like wing, of equal length with the rest of the seed. The nodule has broken naturally in planes parallel to each wing, the planes of least resistance, and I do not

$$
1 \text { Kidston ('04). }
$$

2 Kidston and Jongmans ('11). 
think that more than three wings occur, though this conclusion is at present provisional.

The only seed with which I can compare the British Museum specimen ${ }^{1}$ is Grand' Eury's ${ }^{2}$ Carpolithes oblongus, from the Stephanian of the Loire. Here, however, the seed is only half the size of the British example. I believe that both these seeds belong to the same genus, for it will be remembered that Grand' Eury also concluded that his seed had three wings. I think this type is certainly worthy of removal from the nondescript genus Carpolithus, and to be placed in a genus of its own, for which I propose the name Pterospermum ('winged seed'). As the British example appears to be of so very different dimensions to the French, I propose to distinguish the former as Pterospermum anglicum, sp. nova.

\section{Systematic List of British Coal Measure Seed impressions.}

Genus Trigonocarpus, Brongniart, I 828.

Pleomorphic impressions or casts of seeds, of medium or large size, elongately oval, usually longer than broad, unsymmetrically winged, the apex being produced into a micropyle. Testa differentiated into a soft outer sarcotesta and a hard inner sclerotesta. Inner surface of sclerotesta, with three well-marked grooves, appearing as three longitudinal ridges on the casts of this surface, more or less equidistant.

(I) Trigonocarpus Parkinsoni, Brongn.

T. Parkinsoni, forma a. Impressions of the external surface of the seed. Type Carpolithes alata, Lindley and Hutton, ' Fossil Flora,' Vol. ii, P1. LXXXVII, Figs. I-3, 1833. Recorded from the Transition, Middle, and Lower Coal Measures of many of the Midland, Pennine, North of England, and Scottish coalfields.

Seed elongate, oval, $3 \cdot 5-5 \cdot 5 \mathrm{~cm}$. long, and $\mathrm{x} \cdot 5^{-2} \mathrm{~cm}$. across at greatest width. Micropyle about $\mathrm{I} \cdot 5^{-2} \cdot 5 \mathrm{~cm}$. long, sarcotesta smooth, sclerotesta oval, about $\mathrm{I} \cdot 8 \mathrm{~cm}$. long and $\mathrm{I} \cdot 2 \mathrm{~cm}$. broad at its greatest width.

T. Parkinsoni, forma $\beta$ (Pl. VI, Fig. 2). Impressions of the sclerotesta and micropyle. Type Rhabdocarpus Bochschianus, Berger, 'De Fruct. et Semin. Form. Lith., p. 2I, Pl. I, Figs. 13, I4, I848. Records as above. Sclerotesta oval, smooth, not ridged, $1.8 \mathrm{~cm}$. long and $1.2 \mathrm{~cm}$. at greatest width. Micropyle $\mathrm{I} \cdot 5^{-2} \mathrm{~cm}$. long.

T. Parkinsoni, forma $\gamma$ (Pl. VI, Figs. 3-5). Casts of the inner surface of the sclerotesta. Type Trigonocarpum Nöggerathi, Lindley and Hutton, 'Foss. Flora,' Vol. ii, Pl. CXLII, Figs. C I-3, 1833-35. Records as above.

1 This specimen has for many years past been labelled with a MS. name of Dr. Kidston's.

2 Grand' Eury ('77), p. 187, Pl. XV, Fig. 9. 
Cast ovoid, with three sharp, equidistant longitudinal ridges. Apex pointed, base often rounded, sometimes with a slight umbilicus, but no foramen. Length of cast from $\mathrm{I} \cdot 8-2 \cdot 8 \mathrm{~cm}$, greatest breadth usually less than $\mathrm{I} \cdot 5 \mathrm{~cm}$.

(2) Trigonocarpus Moyseyi, sp. nova.

T. Moyseyi, forma a (P1. I, Fig. I). Impressions of the external surface of the seed. Type Trigonocarpus, sp., Arber, 'Fossil Plants,' Fig. on p. 42, I909; Arber, Proc. Yorks. Geol. Soc., vol. xvii, pt. ii, p. I50 Pl. XVIII, Fig. I, Pl. XIX, Fig. 3, I9Io. Recorded from the Middle Coal Measures of the Notts. and Derby coalfield.

Seed broadly elliptical, $4.2 \mathrm{~cm}$. long and $2.5 \mathrm{~cm}$. across, broadly rounded at each end. Micropyle more than I cm. long, nucule ovate, $\mathrm{I} \cdot 8 \mathrm{~cm}$. long and $\mathrm{I} \cdot 5 \mathrm{~cm}$. brobad at its greatest width, pointed at the apex, broadest at the base. Wing broad, especially at the apex, $2 \cdot 3 \mathrm{~cm}$. broad at the lower termination of the micropyle, ? irregularly plicated. Testa smooth.

$\left.\begin{array}{l}\text { T. Moyseyi, forma } \beta \\ \text { T. Moyseyi, forma } \gamma\end{array}\right\}$ unknown.

(3) Trigonocarpus Dawesi, Lindley and Hutton.

$\left.\begin{array}{l}\text { T. Dawesi, forma } a \\ T \text {. Dawesi, forma } \beta\end{array}\right\}$ unknown.

T. Dawesi, forma $\gamma$ (Pl. VI, Fig. 8), Type, Trigonocarpum Dawesii, Lindley and Hutton, 'Fossil Flora,' vol. iii, Pl. CCXXI, Figs. I and 2, I 837 . Recorded only from the Middle Coal Measures of South Lancashire. Cast similar in every respect to $T$. Parkinsoni, forma $\gamma$, except in dimensions. Cast about $4.5 \mathrm{~cm}$. long and $2.5 \mathrm{~cm}$. across.

(4) Trigonocarpus clavatus (Sternberg) (Text-fig. I). Types, Carpolites clavatus and C. lagenarius, Sternberg, 'Vers. Darstell. Flora d. Vorwelt,' Heft I, Pl. VII, Figs. I4 a, I4 b, 16, 1820; Heft 5-6, pp. xl-xli, 1833 . Recorded from the Transition Coal Measures of the South Lancashire coalfield.

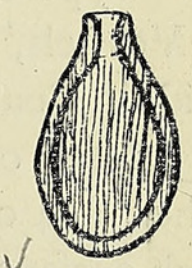

TEXT-FIG. 1 . Trigonocarpus clavatus (Sternb.). After Sternberg.

Seed small, $2 \mathrm{~cm}$. long and $\mathrm{I} \mathrm{cm}$. or more across, flask-shaped, nucule pestle-shaped, micropyle short, sarcotestal wing narrow, apex truncated, testa striated with fine, parallel striae.

Genus Platyspermum, gen. nova.

Seeds of medium size, oval or elongately oval, not winged, testa ornamented with many ribs, approximated or not approximated at the base and apex, with or without fine parallel striations or ribs.

(I) Platyspermum sulcatum (Presl) (P1. VI, Fig. I I).

Type Carpolites sulcatus, Presl in Sternberg, 'Vers. Darstell. Flora d. Vorwelt,' vol. ii, Heft 7, p. 208, Pl. X, Fig. 8, 1838. Recorded from the Transition Coal Measures of South Staffordshire, and from the Middle Coal Measures of Warwickshire and Yorkshire. 
Seeds of medium size, oval or elliptical, broadly rounded at both extremities, about $2.5-3 \mathrm{~cm}$. long, and $\mathrm{I} \cdot 3-\mathrm{I} \cdot 8 \mathrm{~cm}$. across, with about nine, rather prominent and somewhat distant, longitudinal ribs on each side, approximated at base and apex, (?) sometimes confluent.

(2) Platyspermum elongatum, Kidston (P1. VI, Fig. I2).

Type Rhabdocarpus elongatus, Kidston, 'Trans. Geol. Soc. Glasgow,' vol. viii, p. 70, Pl. III, Fig. 6, I886. Recorded from the Middle and Lower Coal Measures of various coalfields in the Midlands and in Scotland.

Seeds small, very narrow, oblong, up to $2 \cdot 3 \mathrm{~cm}$. long, and $3.5-5 \mathrm{~mm}$. wide, rounded at the apex, gradually contracted towards the base. The testa has four or more longitudinal ridges on each side.

(3) Platyspermum Kidstoni, sp. nova (Pl. VI, Fig. 9).

Type Rhabdocarpus multistriatus, Kidston, 'Trans. Roy. Soc. Edinb.,' vol. xxxiii, p. 404, Pl. XXIII, Fig. 4, I888. Recorded from the Upper Coal Measures of Radstock.

Seed oval, $3.5 \mathrm{~cm}$. long, and $2.1 \mathrm{~cm}$. broad, with about eight longitudinal ridges on each side. Ridges approximated at the apex and base. Between the ridges numerous fine, parallel striae occur.

(4) Platyspermum multistriatum (Presl.) non Kidston (P1. VI, Fig. Io).

Type Carpolites multistriatus, Presl. in Sternberg, 'Vers. Darstell. Flora d. Vorwelt,' vol. ii, Heft 7, p. 208, Pl. XXXIX, Figs. I-2, I838. From the Middle Coal Measures of North Staffordshire.

Seed ovate, very broad at one end, somewhat more pointed at the other, 3-4 cm. long, $2 \cdot 2 \mathrm{~cm}$. across at its broadest part. Ribs about nine on each surface, not approximated at apex nor base.

(5) Platyspermum rugosum, sp. nova (Pl. VI, Fig. I3).

Types Nos. I655, 2337, Carbon. Plant Coll., Sedg. Mus., Camb. From the Upper Coal Measures of Radstock, Somerset, and the Middle Coal Measures of the Mattice Hill Boring, Kent, at 1,484 feet.

Seed elongately elliptical, bluntly pointed at both ends, up to $4 \mathrm{~cm}$. or more in length, and about $2 \mathrm{~cm}$. across at broadest part. Ribs broad; prominent, separated by wide, shallow grooves, three to five on each side of seed, ribs approximated at base and apex. Testa smooth or very finely striated.

\section{Genus Cornucarpus, gen. nova.}

Seed small, not winged, triangular in shape, the apex of the triangle being directed downwards and ending in a short stalk, one side of the triangle forming the broad apex of the seed. Two well-marked horns project from the angles at the apex. A median ridge may occur. 
Cornucarpus acutus (Lind. \& Hutt.) (Pl. VI, Fig. I4 and Text-fig. 2).

Type Cardiocarpus acutus, Lindley and Hutton, 'Foss. Flora,' vol. i, p. 209, Pl. LXXVI, 1833 . Recorded from the Transition Coal Measures of Kent, the Middle Coal Measures of Leicestershire, and the Lower Coal Measures of the Newcastle, Ayrshire, and Lanarkshire coalfields.

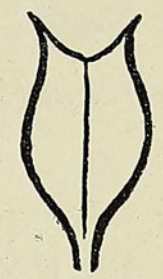

TEXT-FIG. 2. Cormucarpus acutus (L. \& H.). $\times 2$.

Seed triangular, about 6-10 $\mathrm{mm}$. long, with a broad apex, and two wellmarked horns at the angles of the apex. A median ridge extending from apex to base is prominent on most specimens. Testa smooth.

Genus Cardiocarpus, Brongniart, 1828.

Seeds small, heart-shaped or reniform, rounded or emarginate at base, more or less acute at apex, not winged, with or without a narrow, marginal rim.

(I) Cardiocarpus congruens, Grand' Eury (Text-fig. 3).

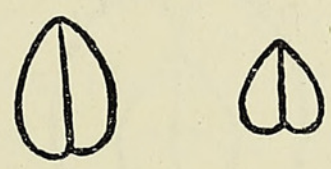

TEXT-FIG. 3. Cardiocarpus congruens, G.' E. After Grand' Eury.

Type Cordaicarpus congruens, Grand' Eury, 'Flore Carbon. Loire,' p. 236, Pl. XXVI, Fig. 2I, J877. Recorded from the Middle Coal Measures of Warwickshire.

Seed small, 6-10 mm. long, apex obtuse. Testa smooth.

(2) Cardiocarpus Gutbieri, Gein. (Pl. VI, Fig. I5).

Type Cardiocarpon Gutbieri, Geinitz, 'Vers. Steinkohlenf. Sachs.,' p. 39, Pl. XXI, Figs. 23-25, I 855. Recorded from the Upper Coal Measures of Radstock, and the Middle Coal Measures of Yorkshire and North Staffordshire.

Seed of medium size, as broad as long or longer than broad, from $\mathrm{I}-2 \mathrm{~cm}$. across, heart-shaped, bluntly pointed at the apex, with or without a very narrow, marginal rim.

Genus Samaropsis, Goeppert, 1864 .

Platyspermic seeds, small or of medium size, more or less circular, not longer than broad, with a sclerotesta, and a well-developed sarcotesta forming a well-marked wing. Sclerotesta usually heart-shaped or ovate. Sarco- 
testa subcircular or heart-shaped, symmetrical or asymmetrical around the sclerotesta. Micropyle usually fairly long.

(1) Samaropsis crassa (Lesq.) (Text-fig. 4).

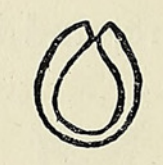

TEXT-FIG. 4. Samaropsis crassus (Lesq.). After Lesquereux.

Type Cardiocarpus crassus, Lesquereux, 'Coal Flora Pennsylv.,' vol. iii, p. P. 8I2, Pl. CIX, Fig. I 2, Pl. CX, Figs. 6-9, I884. Recorded from the Middle Coal Measures of the Leicestershire, and the Lower Coal Measures of the Lanarkshire coalfields.

Seeds small, about I cm. long, oval or subcircular. Nucule large, ovate. Wing narrow, nearly equally symmetrical all round the nucule. Micropylar region pointed.

(2) Samaropsis emarginata, Berger (Text-fig. 5).

Type Cardiocarpon emarginatum, Berger, 'De Fruct. et Semin.'’ p. 24, P1. III, Fig. 35, 1848. Recorded from the Lower Coal Measures of Ayrshire.

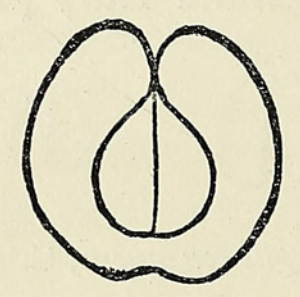

TEXT-FIG. 5. Samaropsis emarginatus (Berg.).

Seeds of fair size, circular, $\mathbf{I} \cdot 3^{-2} \mathrm{~cm}$. in diameter. Nucule large, cordate, pointed above. Wing very broad, but narrower at the base than elsewhere. Micropylar region obtuse.

(3) Samaropsis fluitans (Daws.) (Pl. VI, Fig. I 8).

Type Cardiocarpum fluitans, Dawson, 'Quart. Journ. Geol. Soc.' vol. xxii, p. 165, P1. XII, Fig. 74, I866. Recorded from the Upper, Transition, and Middle Coal Measures of the Southern, Midland, and Pennine coalfields.

Seeds oval, 8-I $5 \mathrm{~mm}$. long, nucule ovate, 4-5 $\mathrm{mm}$. long and $4-6 \mathrm{~mm}$. across. Wing often narrow at the base, produced above the nucule for 2-4 $\mathrm{mm}$. around the micropyle. Micropylar region acute.

(4) Samaropsis Meachemi (Kidst.) (P1. VI, Figs. I6 and I7).

Type Cardiocarpus Meachemii, Kidston, 'Trans. Roy. Soc. Edinburgh,' vol. xxxvi, P1. II, p. 330, Pl. - , Figs. 5-7, I891. Recorded from the Middle Coal Measures of the Kent and South Staffordshire coalfields. 
Seed cordate, about $\mathrm{I} 3 \mathrm{~mm}$. long and broad, base emarginate, apex acute. Nucule cordate, central, with a median ridge extending from apex to centre of base. Wing about $4 \mathrm{~mm}$. broad, and of nearly equal breadth round the nucule. Micropylar region very rounded.

(5) Samaropsis subacuta, Grand' Eury (Text-fig. 6).

Type Samaropsis subacuta, Grand' Eury, 'Flore Carbon. Loire,' p. 28I, P1. XXXIII, Fig. 5, I877. Recorded from the Middle Coal Measures of Yorkshire.

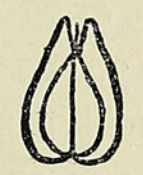

Text-FIG. 6. Samaropsis subacuta, G.' E. After Grand' Eury.

Seed small, ovate or oblong, I cm. long, $7 \mathrm{~mm}$. across. Nucule ovate, keeled, large, apex acute. Wing small, very narrow or absent at the base, broadest at the apex.

Genus Samarospermum, gen. nova.

Winged seeds very elongate and narrow, usually rounded at both ends, and narrowly elliptical in form. Nucule small, elliptical, situated midway between the apex and the base. Sarcotesta with numerous, fine, parallel, longitudinal striae.

Samarospermum moravicum (Helmhacker) (P1. VI, Figs. I9 and 20).

Type Fordania moravica, E. Geinitz, 'Neues Jahrb. Mineral.,' year 1875, p. II, Pl. I, Figs. IO, I I ; Samaropsis moravica, Zeiller, 'Flore Foss. Bass. Houill. et Perm. Brive,' p. 95, Pl. XV, Figs. 9, Io. Recorded from the Middle Coal Measures of the Kent coalfield.

Seed narrowly elliptical, from $2-3 \mathrm{~cm}$. long and $5-8 \mathrm{~mm}$. broad, broadly round at both ends. Nucule central, small, about $6 \mathrm{~mm}$. long and $\mathrm{I} \cdot 5-3 \mathrm{~mm}$. across, elliptical. Sarcotesta with numerous, fine, longitudinal striations.

\section{Genus Rhabdocarpus, Berger, I 848 .}

Seeds large, oval, only symmetrical in one plane, winged, more or less pointed at one extremity, rounded at the other. Nucule large, unsymmetrically oval or semicircular. Wing broad, unsymmetrical. Testa with close, thread-like, longitudinal striae.

Rhabdocarpus Lillieanus, sp. nova (P1. VII, Fig. 21).

Type No. 2034, Carbon. Plant Coll., Sedgwick Mus., Camb. (Lillie Collection). Upper Coal Measures (Farrington Series), Coal Pit Heath Colliery, Bristol coalfield.

Seed broadly oval, exceeding $4 \mathrm{~cm}$. in length and $3 \mathrm{~cm}$. in width at its greatest breadth, somewhat contracted towards the bluntly pointed apex. Base unknown. Central portion of seed rugose, with irregular 
wrinkles or ridges, transverse or oblique, and a faint outline of large nucule. Testa smooth, striae fine and thread-like.

Genus MicRospermum, gen. nova.

Seed small, symmetrical only in a single plane, with a large foramen. Seed flattened, the two sides being dissimilar.

Microspermum samaroides (Carpent.) (P1. VII, Figs. 22-27).

Type Carpolithes ? samaroides, Carpentier, 'Comp. Rend. Assoc. franç. Avanc. Scienc.', Lille, 1909; Notes et Mém., p. 599, I910 ; and 'Rev. Gén. Bot.,' vol. xxiii, p. 7, Pl. XIV, Fig. 3, I9I I. From the Lower Coal Measures of Trowell Colliery (Horizon of the Kilburn Coal), Nottingham.

Seed small, ovate or pyriform in shape, $5^{-12} \mathrm{~mm}$. long and $2.5^{-6} \mathrm{~mm}$. across at its greatest width. One extremity broadly rounded, the other acute. Seed flattened, unsymmetrical ; one side with a strong keel extending from the pointed end nearly to the opposite extremity; the other side more or less convex, with a slight median groove, on either side of which are several faint longitudinal striations, converging towards the pointed end. A large foramen occurs at the broader end on the grooved surface, and more rarely a small foramen is also seen at the pointed extremity.

Genus Cordaicarpus, Geinitz, I 862.

Seeds rather small, oval or orbicular. Testa smooth, not ribbed or striated longitudinally.

(1) Cordaicarpus areolatus (Boul.) (Text-fig. 7).

Type Cardiocarpus (Cordiacarpus) areolatus, Boulay, 'Rech. Pal. Végét. Terr. Houill. Nord France,' p. 34. Recorded from the Middle Coal Measures of Warwickshire.

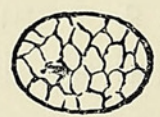

TeXT-FIG. 7. Cordaicarpus areolatus (Boul.). $\times 2$.

Seed small, orbicular, 4-6 $\mathrm{mm}$. in diameter, the testa ornamented with a network of large, polygonal meshes, not very prominent.

(2) Cordaicarpus Cordai, H. B. Geinitz (Pl. VII, Fig. 29).

Type, Carpolithus Cordai, Geinitz, 'Vers. Steinkohlenf. Sachsen,' p. 4I, Pl. XXI, Figs. 7-16. Recorded from the Middle Coal Measures of several coalfields in England.

Seed of fair size, orbicular, 8-20 mm. in diameter. Testa smooth.

(3) Cordaicarpus ovoideus (Berg.) (Pl. VII, Fig. 30).

Type Rhabdocarpos ovoideus, Berger, 'De Fruct. et Semin.,' p. 22, P1. I, Fig. I7. Recorded from the Upper Coal Measures of Radstock, and the Middle Coal Measures of South Staffordshire and Yorkshire. 
Seed small, oval or elliptical or almost orbicular, between $6-10 \mathrm{~mm}$. along the greatest diameter, both extremities rounded or more or less pointed.

\section{Genus Megalospermum, gen. nova.}

Seeds very large, 6-10 cm. long, subcircular or elliptical, blunt at both ends, without longitudinal ridges. Testa ornamented by a series of close, fine, thread-like striae.

Megalospermum Wildi (Kidst.) (Pl. VII, Fig. 28).

Type Carpolithus Wildii, Kidston, 'Trans. Manchester Geol. Soc.,' vol. xxi, p. 408, Fig. on p. 408. Recorded from the Middle Coal Measures of the South Lancashire coalfield.

Seed oblong, $6 \mathrm{~cm}$. long and $3 \mathrm{~cm}$. broad, rounded at the apex, very slightly narrowed at the base, stalked.

Genus Radiospermum, gen. nova.

Seeds cylindrical or ellipsoidal in form, longer than broad, not winged, apex with or without notches or lobes. Testa smooth, with or without a few distant longitudinal ridges but not striated longitudinally. Seeds with or without a cupule.

(I) Radiospermum elongatum, sp. nova (Pl. VII, Figs. 42-43).

Types Nos. 2177 and 2990, Carbon. Plant Coll., Sedgwick Museum, Camb. From the Upper Coal Measures of Radstock and Bishop Sutton, Somersetshire.

Seed oval or elongately elliptical, $3 \cdot 5^{-4} \cdot 5 \mathrm{~cm}$. long and $\mathrm{I} \cdot 3^{-\mathrm{I}} \cdot 5 \mathrm{~cm}$. across, slightly rounded at both ends. Testa smooth, with very slight, distant longitudinal ribs, about $2 \mathrm{~mm}$. apart at a point midway between base and apex.

(2) Radiospermum grande, sp. nova (Pl. VIII, Figs. 44, 45).

Type No. I668, Carbon. Plant Coll., Sedgwick Museum, Camb. Known from the Upper Coal Measures of the Radstock and Forest of Dean coalfields, and the Middle Coal Measures of South Lancashire (No. $5^{2} 5^{84}$ in the Brit. Mus. Nat. Hist.).

Seed large, cylindrical, broadly rounded at each end, $3-5 \mathrm{~cm}$. long, $2.5-3.5 \mathrm{~cm}$. broad. Testa smooth, with three longitudinal, rounded ribs, and short, discontinuous, microscopic grooves.

(3) Radiospermum inflatum (Lesq.) (Text-fig. 8).

Type Rhabdocarpus inflatus, Lesquereux, 'Coal Flora Pennsylv.,' vol. iii, p. P. 8 I 5 , Pl. CX, Fig. 36, I884. Recorded from the Middle Coal Measures of Yorkshire and South Lancashire.

Seed large, up to $4 \mathrm{~cm}$. long, ovoid, broadly rounded at one end and obtusely pointed at the other. Testa smooth, wrinkled, without ribs or striae. 
(4) Radiospermum Kidstoni (Arber) (Plate II, Figs. 35, 36).

Type Lagenostoma Kidstoni, Arber, ' Proc. Roy. Soc. London,' vol. B. 76 , p. 247, P1. I, Figs. I-4; Pl. II, Figs. I-6. Recorded from the Lower Coal Measures of the Lanarkshire coalfield.

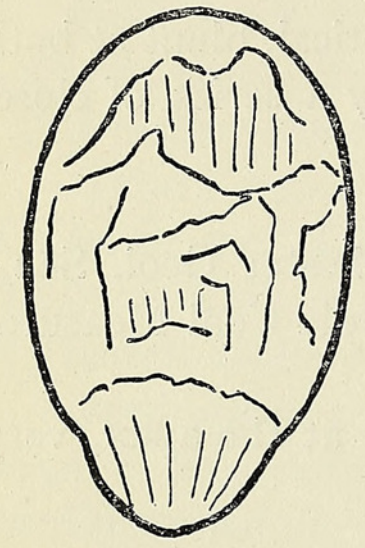

Text-Fig. 8. Radiospermum inflatum (Lesq.). After Lesquereux.

Seeds small, elliptical, $6 \mathrm{~mm}$. long, $2 \cdot 5-3 \mathrm{~mm}$. at greatest breadth. Testa smooth, slightly ridged longitudinally. Apex with several, up to six, wellmarked lobes. No cupule.

(5) ? Radiospermum marginatum (Art.) (Pl. VIII, Fig. 46).

Type Carpolithus marginatus, Artis, 'Antedil. Phytol.,' P1. XXII, B \& C, I825. Recorded from the Middle Coal Measures of the Wyre Forest and Yorkshire coalfields.

Seed fairly large, ? radiospermic, subcircular, $2-2 \cdot 5 \mathrm{~cm}$. across, with a very narrow marginal rim. Testa smooth, unornamented.

(6) Radiospermum ornatum, sp. nova (P1. VII, Figs. 38-4I).

Types No. I 890, I 894, and 2 I I I, Carbon. Plant Coll., Sedgwick Museum, Camb. From the Middle Coal Measures, above the Top Hard Coal, Shipley Clay Pits, Derbyshire.

Seed rather small, elongately triangular, tapered at both ends, rounded at one extremity, rather pointed at the other, I $2-15 \mathrm{~mm}$. long, each side of triangle about 5-6 $\mathrm{mm}$. broad. Testa with twelve longitudinal ridges, three main ridges at the angles, and three minor, slightly less prominent ridges between each pair of major ridges. All ridges approximated at both extremities. Testa ornamented with conspicuous, approximated, transverse striations.

(7) Radiospermum ovatum (L. and H.) (PI. VII, Fig. 32).

Type Trigonocarpum ovatum, Lindley and Hutton, 'Foss. Flora,' vol. ii, Pl. CXLIIA. Recorded from the Middle Coal Measures of Coalbrookdale and Yorkshire.

Casts elongately ovoid, $4.5^{-6} \mathrm{~cm}$. long and up to $3.5 \mathrm{~cm}$. broad, rounded at one end, and slightly narrowed at the other, at which there is a foramen through which an inner cast may or may not project. Testa smooth, with three equidistant, blunt, longitudinal ridges.

(8) Radiospermum perpusillum (Lesquereux) (P1. VII, Fig. 3I).

Type Carpolithes perpusillus, Lesquereux, 'Coal Flora Pennsylv.,' vol. iii, p. P. 825, Pl. CXI, Figs. 22-24. Recorded from the Middle Coal Measures of the Midland, Pennine, and Welsh Borderland coalfields, and from the Lower Coal Measures of the Scottish coalfields.

Seeds minute, cylindrical, about $3 \mathrm{~mm}$. long. Testa smooth, with at least 
one fairly prominent ridge, slightly tapered at one extremity, rounded at the other.

(9) Radiospermum problematicum, sp. nova (Pl. VII, Fig. 37).

Type No. 2669, Carbon. Plant Coll., Sedgwick Museum, Camb. From the Middle Coal Measures of the Wyre Forest coalfield.

Seed ovoid, about $4 \mathrm{~cm}$. long and $2 \mathrm{~cm}$. across at its greatest breadth, broadly pointed at one end and rounded at the other, at which it splits up into several valves. Testa smooth, with very fine and close discontinuous striae, and more than five (? ten) not very prominent, and somewhat distant longitudinal ridges.

(10) Radiospermum Sinclairi (Arber) (P1. VII, Figs. 33-34).

Type Lagenostoma Sinclairi, Arber, 'Proc. Roy. Soc. London,' vol. B. 76 , p. 25I, Pl. II, Figs. 7-II. Recorded from the Lower Coal Measures of the Ayrshire coalfield.

Seed small, elliptical-oblong in shape, $4-5.5 \mathrm{~mm}$. long and $\mathrm{I} \cdot 5-3 \mathrm{~mm}$. broad. Testa smooth, slightly ridged longitudinally. Apex notched or fluted. Cupule $8-9.5 \mathrm{~mm}$. long, sac-like in form, prominently ridged longitudinally, and divided at the apex into a number of lanceolate, erect lobes.

\section{Genus NeURospermum, gen. nova.}

Seeds large, oval or subcylindrical, not winged. Testa with numerous fine, parallel, longitudinal striations.

Neurospermum Kidstoni, sp. nova (P1. VIII, Fig. 47).

Type, cf. Rhabdocarpus, sp. Kidston, 'Phil. Trans. Roy. Soc.', Ser. B, vol. cxcvii, p. I, P1. I, I904. Recorded from the Middle Coal Measures of the South Staffordshire coalfield.

Seed cylindrical, about $2.8 \mathrm{~cm}$. long and $\mathrm{I}-\mathrm{I} \cdot 4 \mathrm{~cm}$. across, contracted towards the apex into a somewhat sharp point.

\section{Genus Schizospermum, gen. nova.}

Seeds of medium size, ovately triangular, splitting at the apex into three valves along the angles of the triangle, each valve having usually a median longitudinal ridge. At the base a foramen occurs, through which an inner cast is seen.

Schizospermum Noeggerathi (Sternb.) (P1. VIII, Figs. 48-50).

Type Palmacites Noeggerathi, Sternberg, 'Vers. Darstell. Flora Vorwelt,' Heft 4, p. xxxv, Pl. LV, Figs. 6, 7, I826. Recorded from the Upper, Transition, and Middle Coal Measures of various coalfields in the South of England, South Wales, and the Pennine fields.

Seeds short, ovoidly triangular, $2 \cdot 5-4 \mathrm{~cm}$. long, $\mathrm{I} \cdot 2-3 \mathrm{~cm}$. broad, rounded at the base, obtusely pointed at the apex, splitting into three valves along the angles of the triangle, each valve having a less well-marked median ridge. Foramen at base large. 


\section{Genus Pterospermum, gen. nov.}

Seeds large, elongate, angular in section, the angles being produced into flap-like, broad wings, nearly as long as the main portion of the seed.

Pterospermum anglicum, sp. nova (P1. VIII, Figs. 5I-52).

Type V. I 183, Geol. Dept., British Museum (Nat. Hist.), from the Middle Coal Measures of South Staffordshire. The only known example.

Seed large, (?) triangular in section, which is of small area, elongate, $5 \cdot 5^{-6} \mathrm{~cm}$. long and $2 \cdot 3-2 \cdot 6 \mathrm{~cm}$. across between the wings. Three (? more) large, flap-like wings arise one from each angle, $5 \mathrm{~cm}$. long and $2 \mathrm{~cm}$. or more in breadth. Testa smooth.

\section{BIBLIOGRAPHY.}

Arber, E. A. N. ('05): On some New Species of Lagenostoma, a type of Pteridospermous Seed from the Coal Measures. Proc. Roy. Soc., Ser. B, vol. lxxvi, I905, p. 245.

('09) : Fossil Plants. Gowan and Gray's Nature Series, No. 21, Glasgow, I909.

('10): On the Fossil Flora of the Southern Portion of the Yorkshire Coalfield in

North Derbyshire and Nottinghamshire. Proc. York. Geol. Soc., vol. xvii, pt. ii, 1910, p. I32.

Berger, R. ('48) : De Fructibus et Seminibus ex Formatione Lithanthracum. Vratislaviae, I848.

Bertrand, C. E. ('11) : Le bourgeon femelle des Cordaïtes d'après les préparations de Bernard Renault. Bull. soc. sci., Nancy, I9I I.

Brongniart, A. ('28): Prodrome d'une histoire des végétaux fossiles, 1828.

Carpentier, A. ('10): Note sur quelques végétaux fossiles du bassin houiller du Nord. Compt. Rend. Assoc. franc. Avanc. Sci., Lille, I909; Notes et Mém., I9IO, p. 599.

('11) : Sur quelques fructifications et inflorescences du Westphalien du Nord de la France. Rev. génér. bot., vol. xxiii, I9II, p. I.

Feistmantel, K. ('81): Der Hangendfötzzug im Schlan-Rakonitzer Steinkohlenbecken. Arch. naturwiss. Landesdurchf. Böhm., Prag, vol. iv, I88ı, No. 6, Geolog. Teil, p. I.

Fiedler, H. ('57): Die fossilen Früchte der Steinkohlen-Formation. Verhandl. K. Leop.-Carol. Akad. Naturf., vol. xxvi, I857, p. 24 I.

Geinitz, E. ('75): Über neue Aufschlïsse im Brandschiefer der unteren Dyas von Weissig, bei Pillnitz in Sachsen. Netues Jahrb. Mineral., I875, p. I.

Geinitz, H. B. ('61) : Dyas oder die Zechsteinformation und das Rothliegende. Leipzig, I86I-2.

Grand' Eury, C. ('77): Flore carbonifère du département de la Loire et du Centre de la France. Mém. sav. étrang. Acad. Sci., vol. xxiv, I877, No. I.

Helmhacker, R. ('71) : Über einige neue Vorkommnisse von böhmischen Mineralien und Petrefakten. Sitzungsb. K. Böhm. Gesellsch. Wissensch., Prag, ı 87 I, p. 77 .

Kidston, R. ('88) : On the Fossil Flora of the Radstock Series of the Somerset and Bristol Coalfield (Upper Coal Measures). Trans. Roy. Soc., Edinb., vol. xxxiii, I888, part II, p. 335 . ('89:) On the Fossil Plants in the Ravenhead Collection in the Free Library and Museum, Liverpool. Trans. Roy. Soc., Edinb., vol. xxxv, 1889, pt. II, p. 39 I.

('94): On the Various Divisions of British Carboniferous Rocks as determined by their Fossil Flora. Proc. Roy. Phys. Soc., Edinb., vol. xii, I 894, p. I83.

('04): On the Fructification of Neuropteris heterophylla, Brongniart. Phil. Trans. Roy. Soc., Ser. B, vol. cxcvii, I904, p. I.

Kidston, R., and Jongmans, W. J. ('11) : Sur la fructification de Neuropteris obliqua, Bgt. Arch. Néerland. sci. exact. et nat., $3^{\text {e }}$ sér., B., vol. i, I9I I, p. 25. 
Lindeey, J., and Hutton, W. ('31): The Fossil Flora of Great Britain. Vols. i-iii, London, $183 \mathrm{I}-7$.

Morris, J. ('40) : In Prestwich, On the Geology of the Coalfield of Coalbrook Dale. Trans. Geol. Soc., Ser. 2, vol. v, 1840 , p. 488.

Oliver, F. W. ('03): The Ovules of the Older Gymnosperms. Ann. Bot., vol, xvii, I903, p. 45I.

Oliver, F. W., and Salisbury, E. J. ('11): On the Structure and Affinities of the Palaeozoic Seeds of the Conostoma Group. Ann. Bot., vol. xxv, I9II, p. I.

Renault, B. ('90): Études sur le terrain houiller de Commentry. Lirr. ii, Flore Fossile, $2^{\mathrm{e}}$ partie, Saint-Etienne, 1890.

Scott, D. H., and Maslen, A. J. ('07): The Structure of the Palaeozoic Seeds, Trigonocarpus Parkinsoni, Brongniart, and Trigonocarpus Oliveri, sp. nova. Part I. Ann. Bot., vol. $x x i, 1907$, p. 89.

Sternberg, K. ('20): Versuch einer geognostisch-botanischen Darstellung der Flora der Vorwelt. Leipzig und Prag, 1820-38.

Weiss, C. E. ('79): Beiträge zur fossilen Flora. II. Die Flora des Rothliegenden von Wünschendorf bei Lauban in Schlesien. Abhandl. Geol. Specialk. Preuss., Thür. Staat., vol. iii, pt. i, 1879 .

Woodward, J. (1729): An Attempt towards a Natural History of the Fossils of England, \&c. Tome II : A Catalogue of the Additional English Native Fossils, \&c. London, I 729.

Zeiller, R. ('86): Flore fossile du bassin houiller de Valenciennes. (Étud. Gîtes Minér.) Paris, I $886-8$.

('92): Flore fossile du bassin houiller et permien du Brive. (Étud. Gîtes Minér.)

Paris, 1892 .

('00): Éléments de paléobotanique. Paris, 1900.

\section{EXPLANATION OF THE PLATES}

Illustrating Dr. Newell Arber's Revision of the Seed Impressions of the British Coal Measures.

(The photographs are partly by the author, partly by Mr. Tams, Cambridge.)

PLATE VI.

- Fig. I. Trigonocarpus Moyseyi, sp. nova, forma a. An almost complete impression of the external surface of the seed. From the Middle Coal Measures of Shipley Clay Pit, Derby. The type specimen in Dr. Moysey's collection. $\times \frac{2}{1}$.

- Fig. 2. Trigonocarpus Parkinsoni, Brongn., forma $\beta$. Impression of the sclerotesta and micropyle. From the Middle Coal Measures of Yorkshire. Sedgwick Museum, Cambridge (No. I184, Carbon. Plant Coll.). Nat. size.

Fig. 3. Trigonocarpus Parkinsoni, Brongniart, forma $\gamma$. Tri-ridged casts of the inner surface of the sclerotesta. From the Middle Coal Measures of Peel Quarry, Bolton, Lanc. Sedgwick Museum, Cambridge (No. 485 , Carbon. Plant Coll.). Nat. size.

Fig. 4. Trigonocarpus Parkinsoni, Brongniart, forma $\gamma$. The bases of two specimens seen from above. That of the lower specimen is smooth, that of the upper shows an oval umbilicus. From the Middle Coal Measures of Peel Quarry, Bolton. Sedgwick Museum, Cambridge (No. $4^{8} 5$, Carbon. Plant Coll.). Nat. size.

Fig. 5. Trigonocarpus Parkinsoni, Brongniart, forma $\gamma$. The bases of two further specimens, both showing an umbilicus. From the Middle Coal Measures of Peel Quarry, Bolton. Sedgwick Museum, Cambridge (No. 485 , Carbon. Plant Coll.). Nat. size.

Fig. 6. Trigonocarpus Parkinsoni, Brongn. A petrified example described by Mrs. E. A. N. Arber on p. 195. Median longitudinal section through the seed, showing the micropylar beak of the sclerotesta with great completeness. Binney Coll., Sedgwick Museum, Cambridge, Slide A.B. II. $\times 2.5$ circa.

Fig. 7. Trigonocarpus Parkinsoni, Brongn. A petrified example described by Mrs. E. A. N. 
Arber on p. 195. Part of another longitudinal section through the same seed as that represented in the last figure, showing the connexion between the nucellar wall (to the right) and the seed coat (occupying the whole of the lower left-hand portion of the figure). The nucellar tracheides are visible in the lower half of the figure at the extreme right. Binney Coll., Sedgwick Museum, Cambridge, A.B. I2. $\times$ I 27 circa.

Fig. 8. Trigonocarpus Dawesi, L. and H., forma $\gamma$. A tri-ridged cast of the inner surface of the sclerotesta. From the Middle Coal Measures of Peel Quarry, Bolton, S. Lanc. Sedgwick Museum, Cambridge (No. 490, Carbon. Plant Coll.). Nat. size.

Fig. 9. Platyspermum Kidstoni, sp. nova. From the Upper Coal Measures of Radstock, Som. The type, after Kidston. Nat. size.

Fig. Iо. Platyspermum multistriatum (Sternb.). From the Transition Coal Measures of Longport, North Staffordshire. In the Sedgwick Museum, Cambridge (No. 21 76, Carbon. Plant Coll.). Nat. size.

- Fig. II. Platyspermum sulcatum (Presl.). From the Middle Coal Measures of Ravenshore,

S. Lanc. In the Sedgwick Museum, Cambridge (No. 299I, Carbon. Plant Coll.). Nat. size.

Fig. I 2. Platyspermum elongatum (Kidst.). From the Lower Coal Measures of Trowell Colliery, Nottingham. From a specimen in Dr. Moysey's collection. $\times \frac{6}{5}$.

Fig. I3. Platyspermum rugosum, sp. nova. From the Middle Coal Measures of the Mattice

Hill Boring, Kent, at a depth of $\mathrm{I}, 484 \mathrm{ft}$. Type in the Sedgwick Museum, Cambridge (No. 2337, Carbon. Plant Coll.). Nat. size.

Fig. I4. Cormucarpus acutus (L. and H.). From the Middle Coal Measures of the Goodnestone Boring, Kent, at a depth of 2,000 ft. In the Sedgwick Museum, Cambridge (No. 2230, Carbon. Plant Coll.). Nat. size.

Fig. I5. Cardiocarpus Gutbieri, Gein. From the Middle Coal Measures of the Mattice Hill Boring, Kent, at a depth of I, I I I feet. Sedgwick Museum, Cambridge (No. 2375, Carbon. Plant Coll.). Nat. size.

Fig. I6. Samaropsis Meachemi (Kidst.). From the Middle Coal Measures of the Woodnesborough Boring, Kent, at a depth of $1,65 \mathrm{I} \mathrm{ft}$. Sedgwick Museum, Cambridge (No. 246I, Carbon. Plant Coll.). $\times 3$.

Fig. I7. Samaropsis Meachemi (Kidst.). From the Middle Coal Measures of the Woodnesborough Boring, Kent, at a depth of $I_{1} \mathrm{I}_{6} 6 \mathrm{ft}$. Sedgwick Museum, Cambridge (No. 2465, Carbon. Plant Coll.). $\times \frac{5}{3}$.

Fig. 18. Samaropsis fluitans (Daws.). From the Upper Coal Measures of Camerton, Somerset. Sedgwick Museum, Cambridge (No. $165^{2}$, Carbon. Plant Coll.). Nat. size.

Fig. 19. Samarospermum moravicum (Helmb.). From the Middle Coal Measures of the Oxney Boring, Kent, at a depth of 2,439 ft. In the Sedgwick Museum, Cambridge (No. 2992, Carbon. Plant Coll.). Nat. size.

Fig. 20. Samarospermum moravicum (Helmh.) Enlarged view of the reverse of Fig. 19. $\times 3$.

\section{PLATE VII.}

-Fig. 21. Rhabdocarpus Lillieanus, sp. nova. From the Upper Coal Measures (Farrington Series) of Coal Pit Heath Colliery, Bristol coalfield. Type in the Sedgwick Museum, Cambridge (No. 2034, Carbon. Plant Coll.). Nat. size.

Fig. 22. Microspermum samaroides (Carpent.). A specimen showing the grooved surface and the large foramen at the lower end. From the Middle Coal Measures of Shipley Clay Pit, Derby. Type in Dr. Moysey's collection. Nat. size.

Fig. 23. Microspermum samaroides (Carpent.). The same specimen as Fig. $22 . \times \frac{5}{2}$.

Fig. 24. Microspermum samaroides (Carpent.). A specimen showing the keeled surface. From the same locality and in the same collection. $\times 2$.

Fig. 25. Microspermum samaroides (Carpent.). A specimen of (?) the keeled surface showing a large 'dimple' below, and some indication of (?) a smail foramen at the pointed end. From the same locality and in the same collection. $\times 2$.

Fig. 26. Microspermum samaroides (Carpent.). A specimen showing a foramen at the pointed end, but not very like the other specimens of this species here figured, though probably only another form of the same seed. From the same locality and in the same collection. $\times 2$.

Fig. 2\%. Microspermum samaroides (Carpent.). A specimen showing the grooved surface with 
the foramen at the broader end, similar to Figs. 22 and 23. From the same locality and in the same collection. $\times 2$.

Fig. 28. Megalospermum Wildi (Kidst.). From the Middle Coal Measures of Bardsley, South Lancashire. The counterpart of the type in the Manchester Museum. Nat. size.

Fig. 29. Cordaicarpus Cordai, Gein. Several seeds from the Middle Coal Measures of Kinlet Colliery, Wyre Forest, Shropshire. Sedgwick Museum, Cambridge (No. 2676, Carbon. Plant Coll.). Nat. size.

Fig. 3o. Cordaicarpus ovoideus, Berg. Several seeds from the Upper Coal Measures of Radstock, Somerset. Sedgwick Museum, Cambridge (No. I228, Carbon. Plant Coll.). $\times \frac{9}{7}$.

Fig. 31. Radiospermum perpusillum (Lesq.). From the Middle Coal Measures of Billingsley Colliery, Wyre Forest, Shropshire. Sedgwick Museum, Cambridge (No. 2ךo8, Carbon. Plant Coll.). $\times 3$.

Fig. 32. Radiospermum ovatum (L. and H.). From the Middle Coal Measures of Barnsley, Yorkshire. In the British Museum Collection (V. I I525). Nat. size.

Fig. 33. Radiospermum Sinclairi (Arber). Two seeds enclosed in their cupules and attached to a branched axis. From the Lower Coal Measures of Grange Colliery, Kilmarnock, Ayrshire. In Dr. Kidston's collection. $\times 3$.

Fig. 34. Radiospermum Sinclairi (Arber). A drawing of a seed. From the same locality, and in the same collection. $\times 5$.

Fig. 35. Radiospermum Kidstoni (Arber). Four seeds attached to an axis. From the Lower Coal Measures of Swinhill Colliery, Stonehouse, Lanarkshire. In the British Museum Collection (V. 624I). $\times 2$.

Fig. 36. Radiospermum Kidstoni (Arber). A drawing of a single seed, from the same locality, and in the same collection. $\times 5$.

-Fig. 37. Radiospermum problematicum, sp. nova. The type from the Middle Coal Measures of Kinlet Colliery, Wyre Forest, Shropshire. Type specimen in Sedgwick Museum, Cambridge (No. 2669, Carbon. Plant Coll.). $\times 2$.

Fig. 38. Radiospermum ornatum, sp. nova. A specimen showing the longitudinal ridges, from the Middle Coal Measures of Shipley Clay Pit, Derbyshire. Type specimen in the Sedgwick Museum, Cambridge (No. 2 I I I, Carbon. Plant Coll.). $\times 3$.

Fig. 39. Radiospermum ornatum, sp. nova. A specimen showing the longitudinal ridges and the transverse striations. From the same locality. (Type No. 1890 in the same collection.) $\times 2$.

Fig. 40. Radiospermum ornatum, sp. nova. The same specimen as Fig. 39 (No. 1890). Nat. size.

Fig. 4I. Radiospermum ornatum, sp. nova. The same specimen as Fig. $3^{8}$ (No. 2 III). Nat. size.

Fig. 42. Radiospermum elongatum, sp. nova. From the Upper Coal Measures of Bishop Sutton Colliery, Somerset. Type specimen in the Sedgwick Museum, Cambridge (No. 2990, Carbon. Plant Coll.). Nat. size.

Fig. 43. Radiospermum elongatum, sp. nova. From the Upper Coal Measures of Radstock, Somerset. Type specimen in the Sedgwick Museum, Cambridge (No. 21 77, Carbon. Plant Coll.). $\times \frac{5}{3}$.

\section{PLATE VIII}

Fig. 44. Radiospermum grande, sp. nova. From the Middle Coal Measures of Wigan, South Lancashire. Type specimen in the British Museum Collection, No. $5^{25} 84$. Nat. size.

Fig. 45. Radiospermum grande, sp. nova. From the Upper Coal Measures of Trafalgar Colliery, Forest of Dean, Gloucestershire. Type specimen in the Sedgwick Museum, Cambridge (No. 1668, Carbon. Plant Coll.). Nat. size.

Fig. 46. ? Radiospermum marginatum (Art.). From the Middle Coal Measures of the Alton Boring, Dowles Valley, Wyre Forest, Worcestershire. Sedgwick Museum, Cambridge (No. 2594, Carbon. Plant Coll.). Very slightly enlarged.

Fig. 47. Neurospermum Kidstoni, sp. nova. From the Middle Coal Measures of Clays Croft, Coseley, S. Staffordshire. Type specimen in the Sedgwick Museum, Cambridge (No. 2986, Carbon. Plant Coll.). Nat. size.

- Fig. 48. Schizospermum Noeggerathi (Sternb.). Side view of the seed. From the Upper Coal 
Measures (Farrington Series) of Coal Pit Heath Colliery, near Bristol. Sedgwick Museum, Cambridge (No. 2032, Carbon. Plant Coll.). Nat. size.

-Fig. 49. Schizospermum Noeggerathi (Sternb.). View of the apex of the seed showing the three valves. From the Middle Coal Measures of Darfield Quarry, Barnsley, Yorks. Sedgwick Museum, Cambridge (No. 729, Carbon. Plant Coll.). Nat. size.

- Fig. 50. Schizospermum Noeggerathi (Sternb.). View of the base of the seed showing the foramen and inner cast. From the (?) Middle Coal Measures. Sedgwick Museum, Cambridge (No. 487, Carbon. Plant Coll.). Nat. size.

Fig. 51. Pterospermum anglicum, sp. nova. Part of a specimen showing two of the three wings. From the Middle Coal Measures of Clays Croft, Coseley, S. Staffordshire. Type specimen in the British Museum (Nat. Hist.), No. V. I 83 . Nat. size.

Fig. 52. Pterospermum anglicum, sp. nova. Part of the same specimen as Fig. $5 \mathrm{I}$, showing one of the wings seen in that figure and a third wing. From the same locality and collection. Nat. size. 
Annals of Botany.

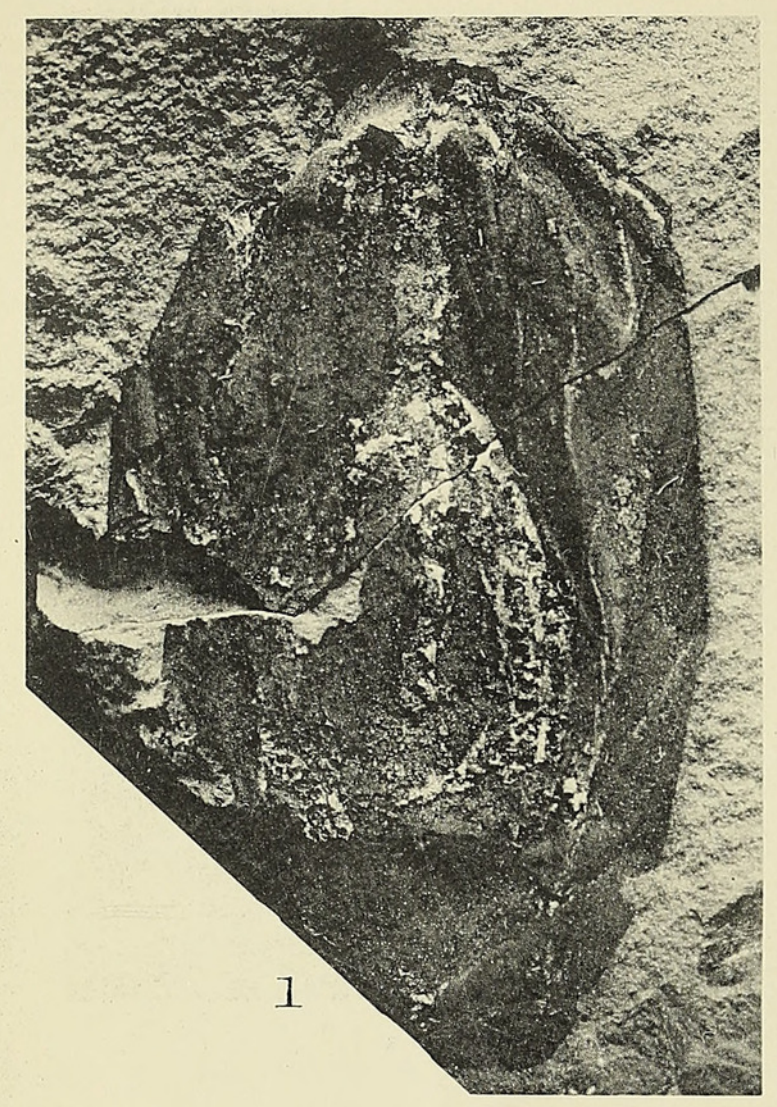

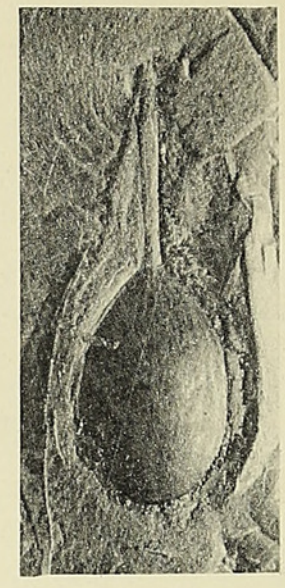

2

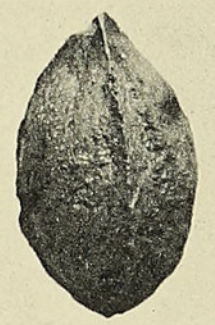

3

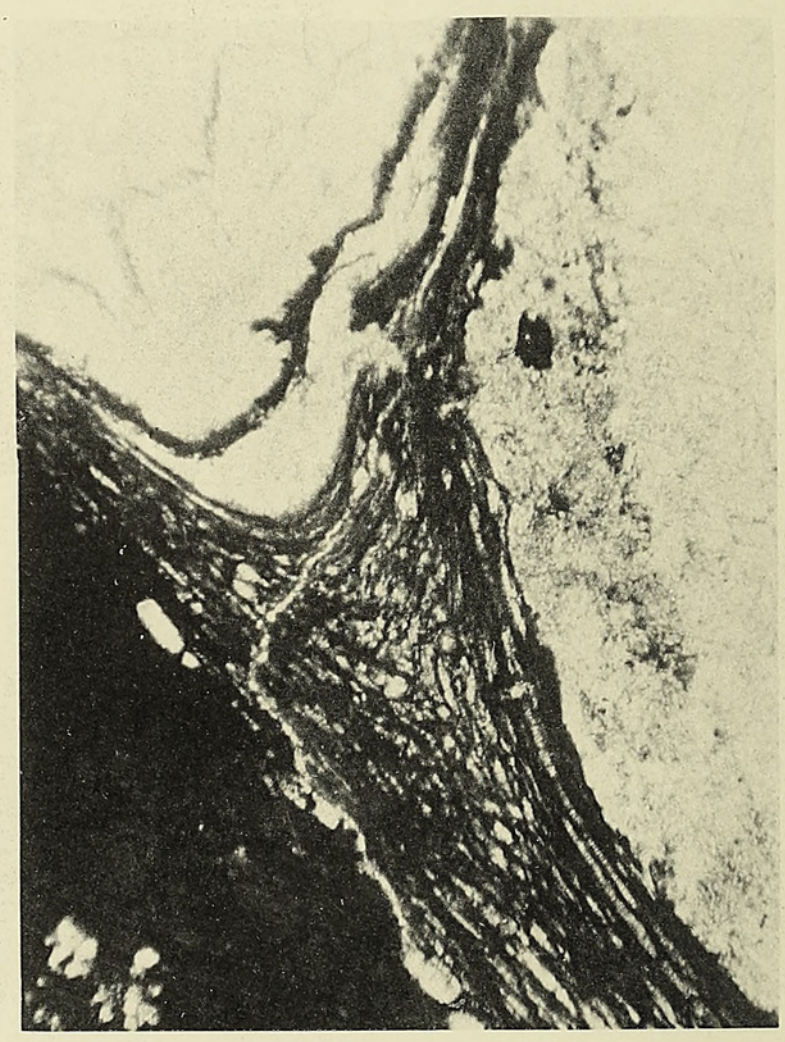

7
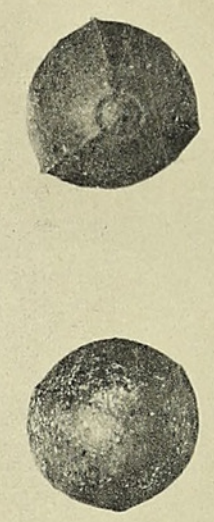

4

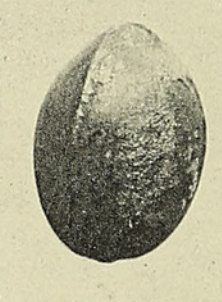

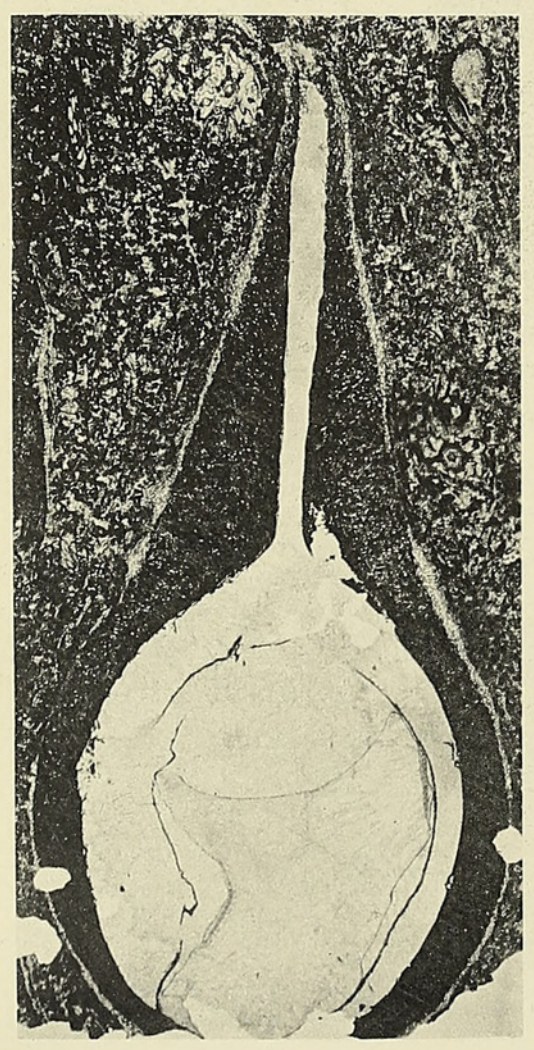

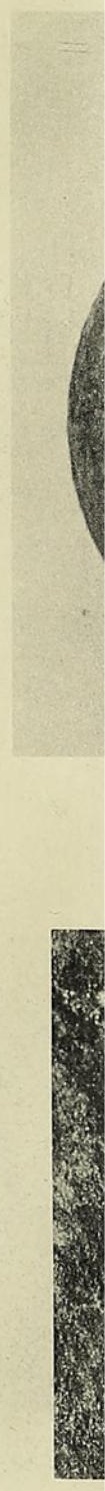

6
E.A.N.A.\&W.Tams, Photo.
ARBER - SEED
IMPRESSIONS 


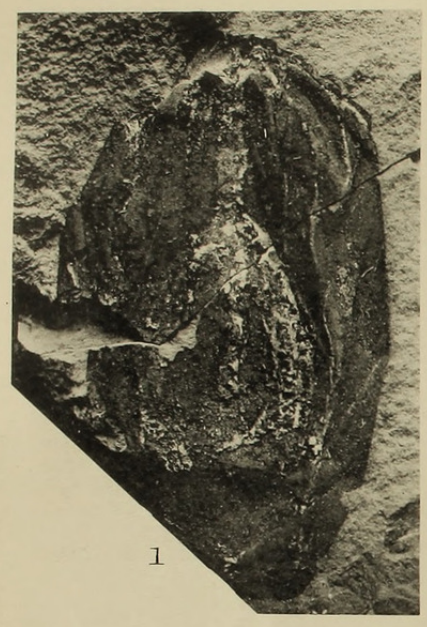

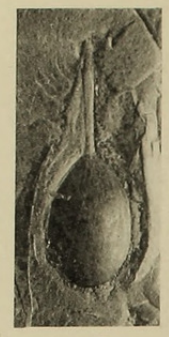

2
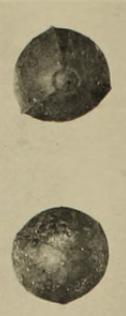

4

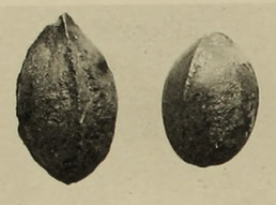

3
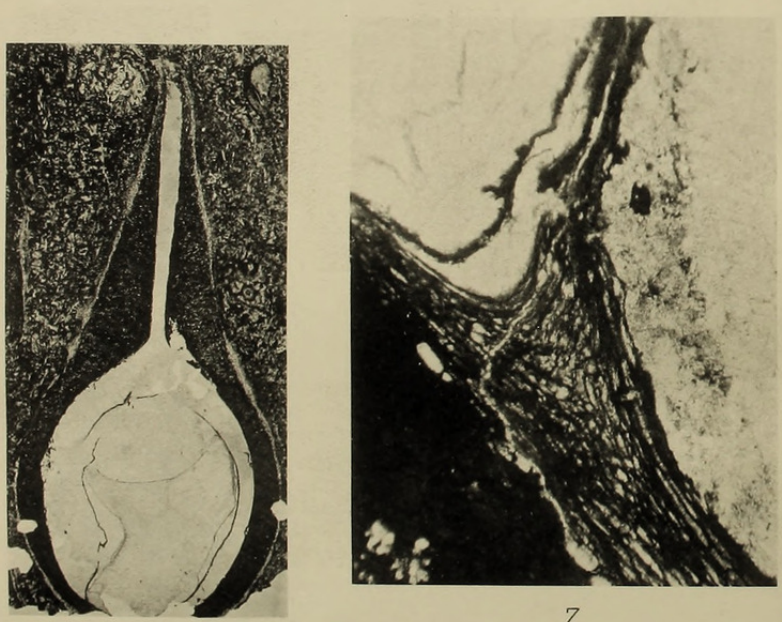

7
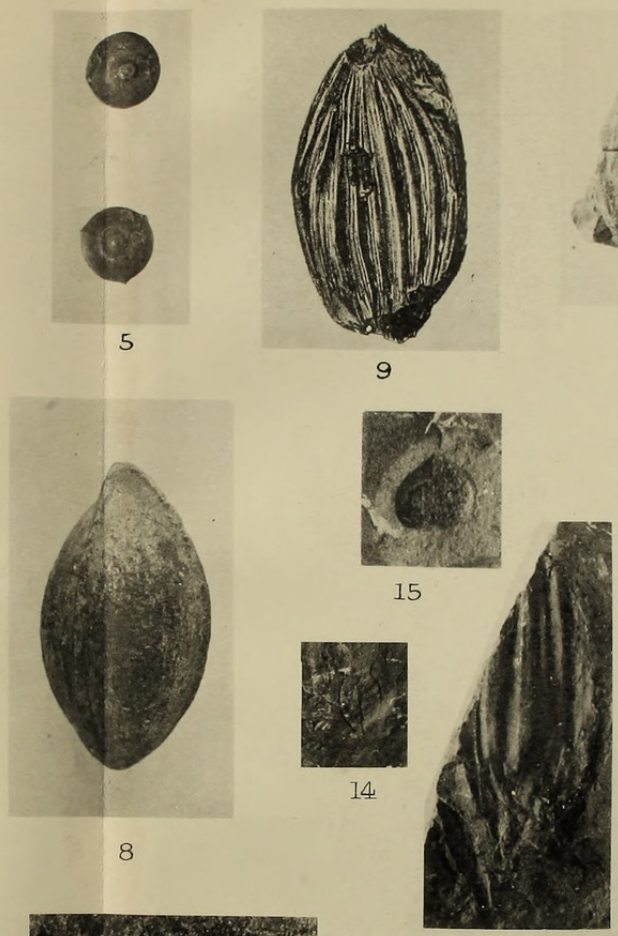

13

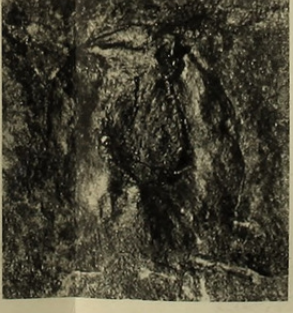

16
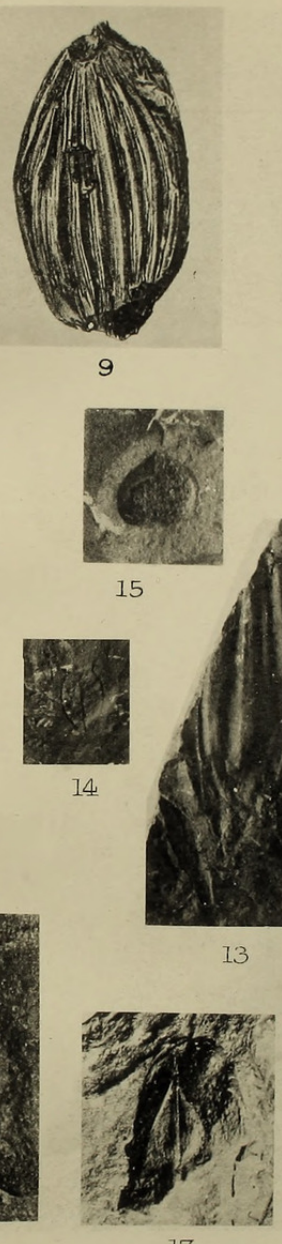

17
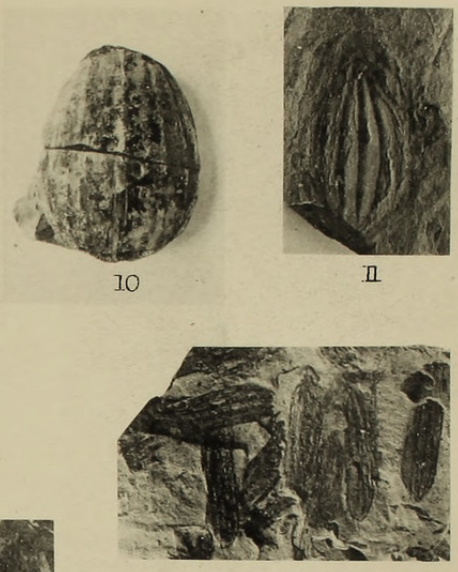

12

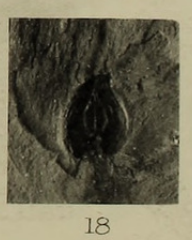

18
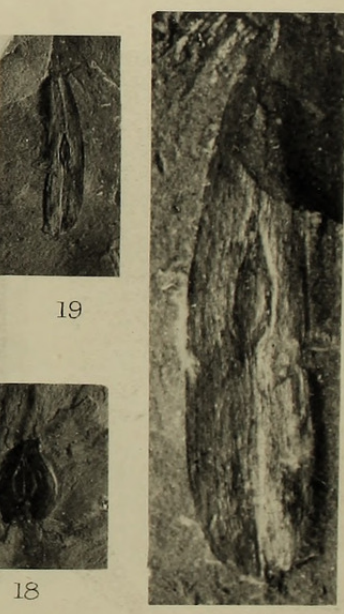

20 
Annals of Botany

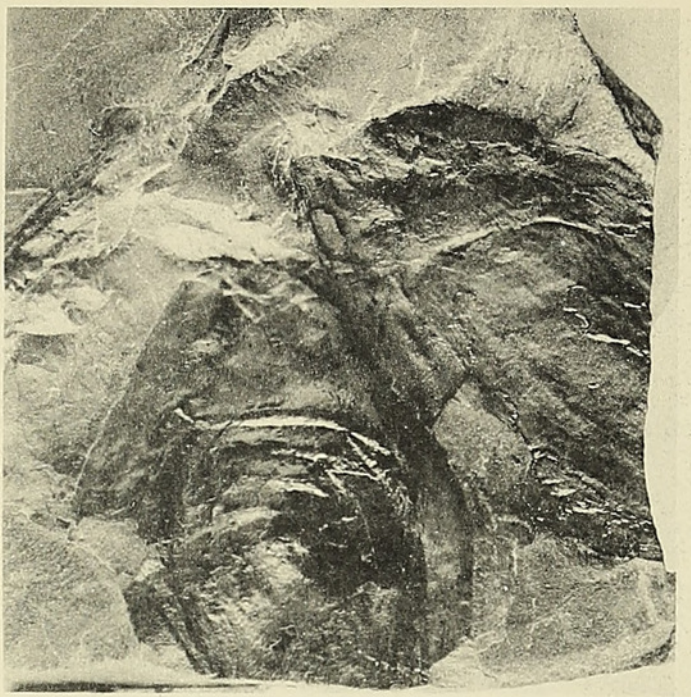

21

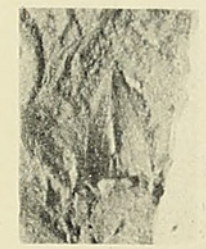

22

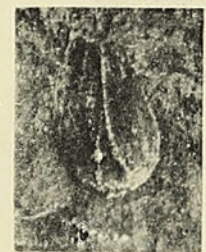

24

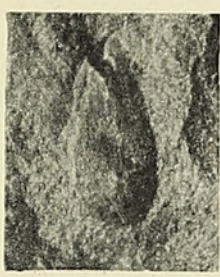

26

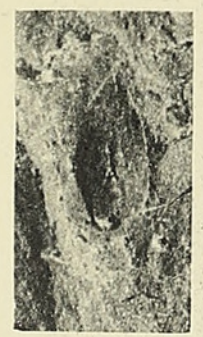

27

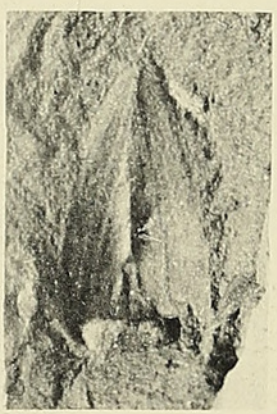

23

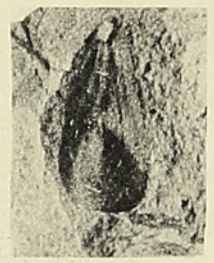

25

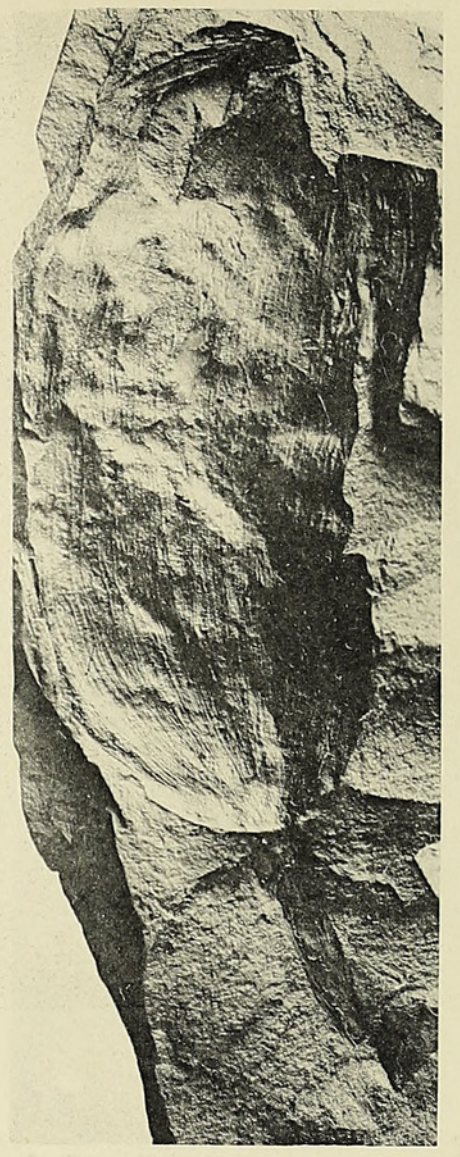

28

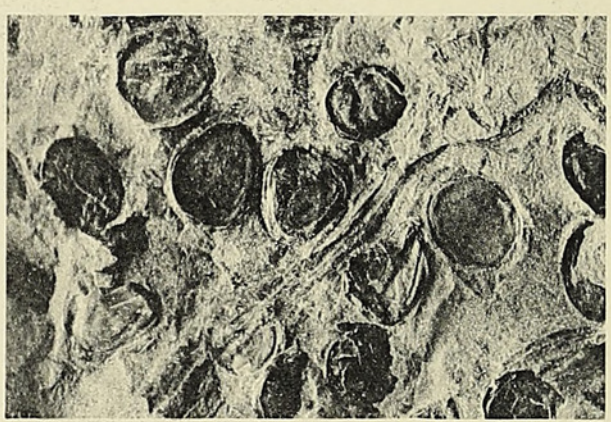

29
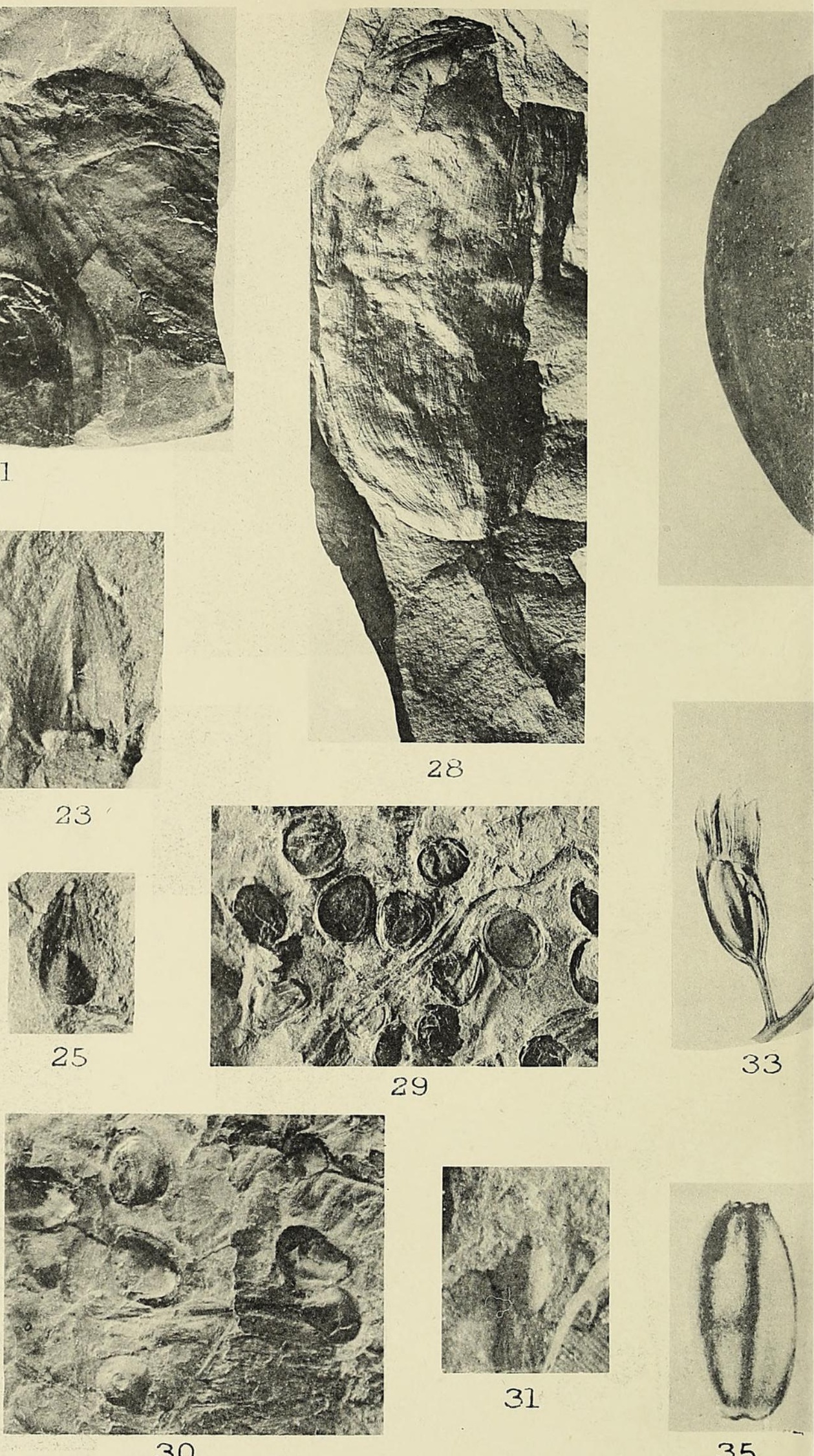

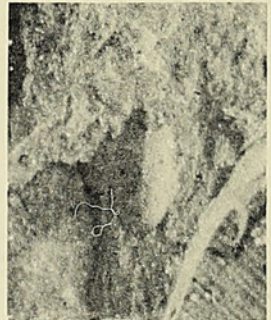

31

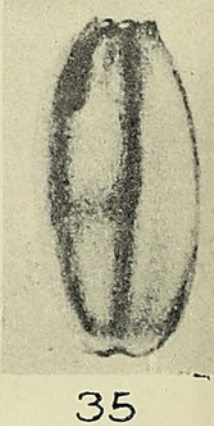

E.A.N.A\&.W.Tams Photo. 


\section{Vol.XXVIII, PZ.VII.}
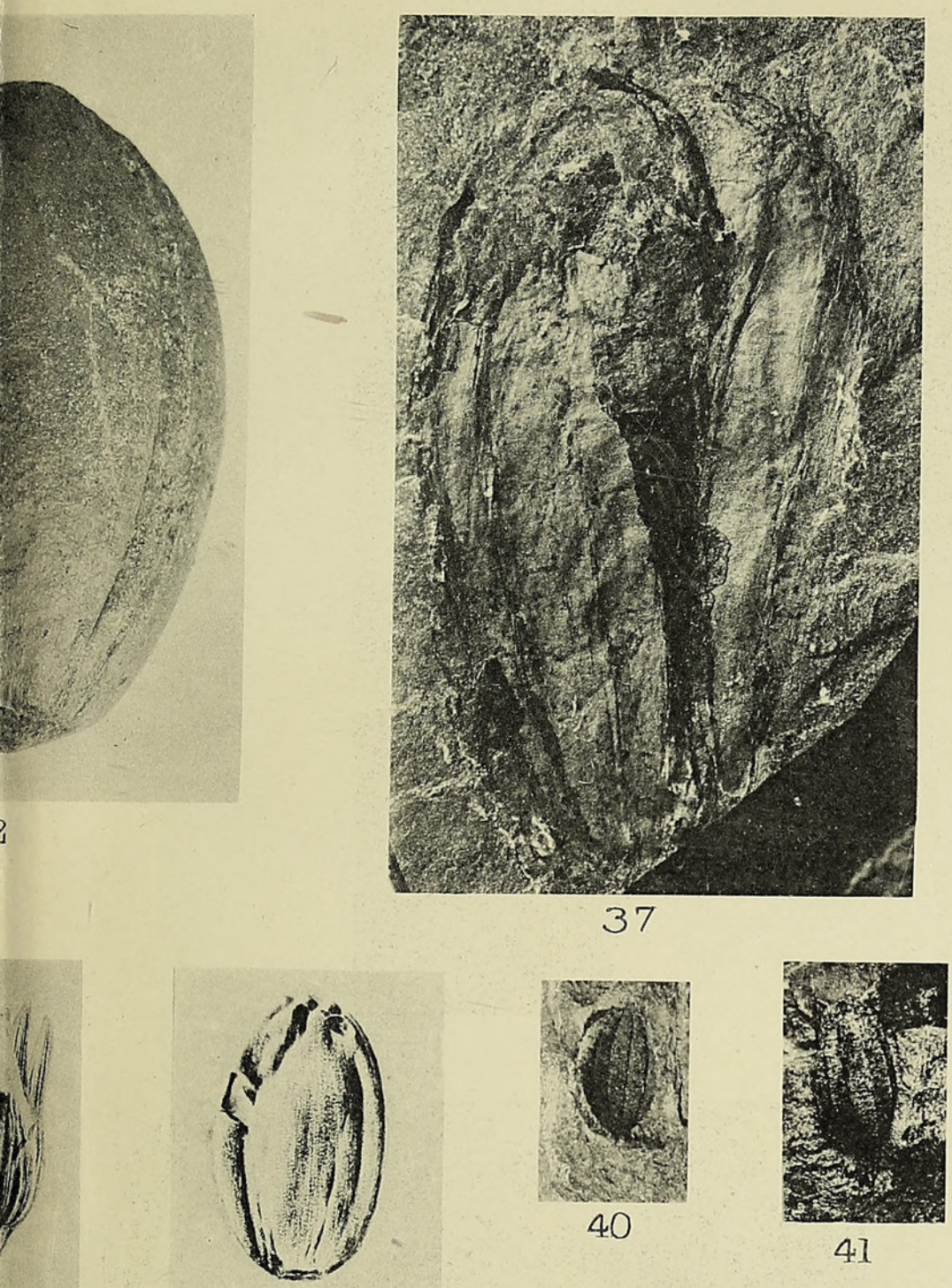

34

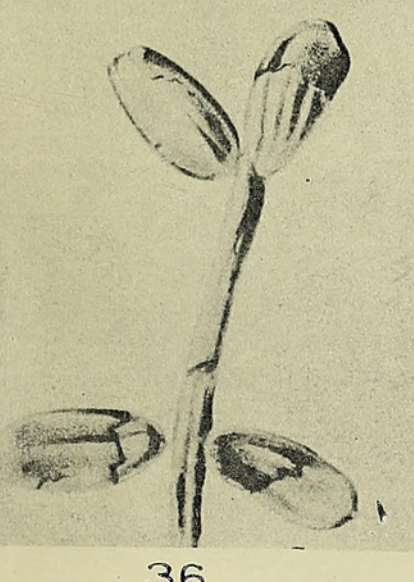

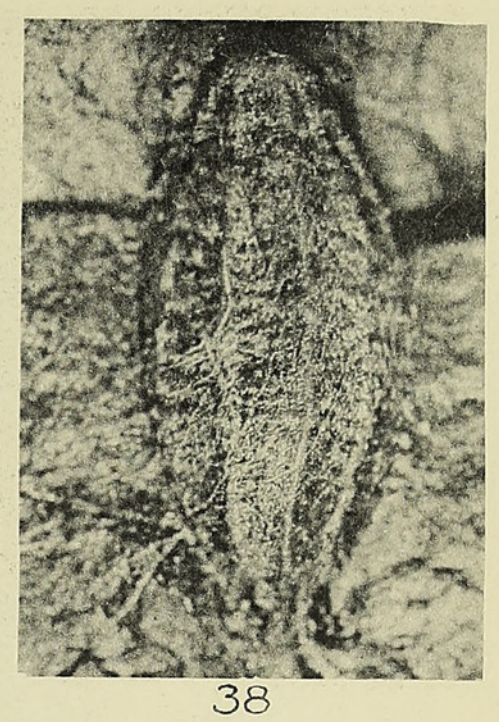

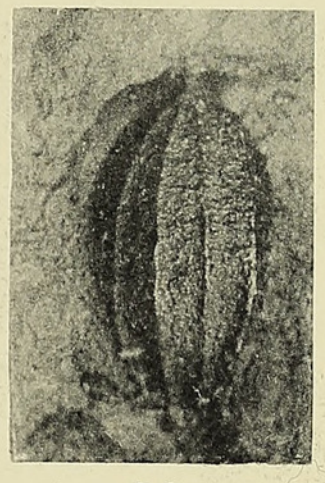

39

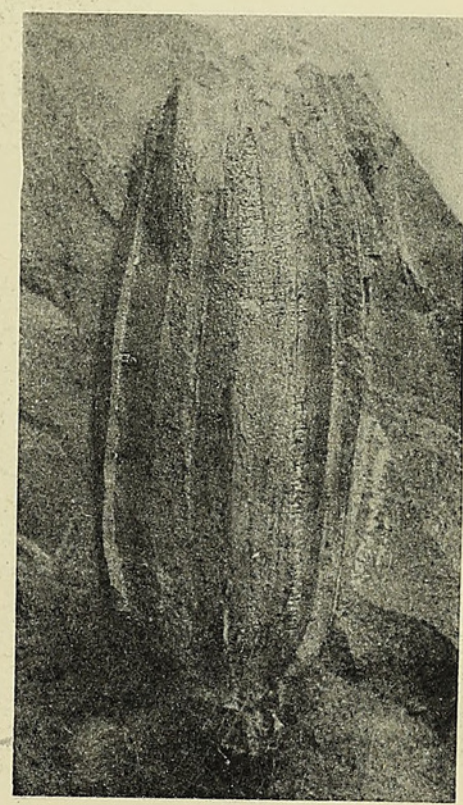

43

Hoth caIl. 


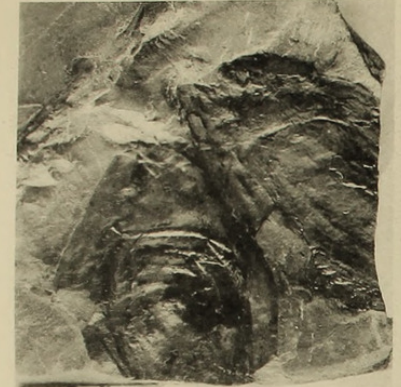

21

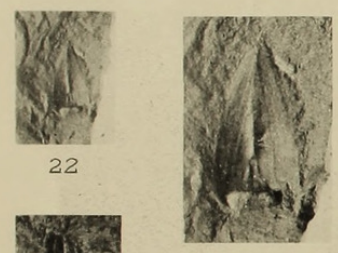

23

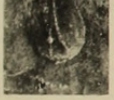

24

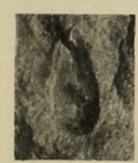

26

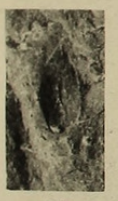

27

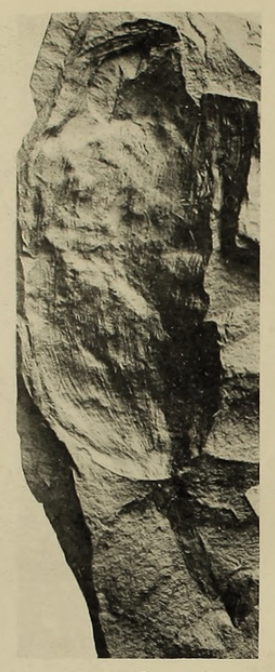

28

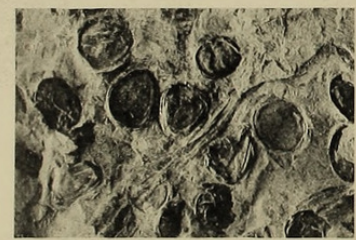

29
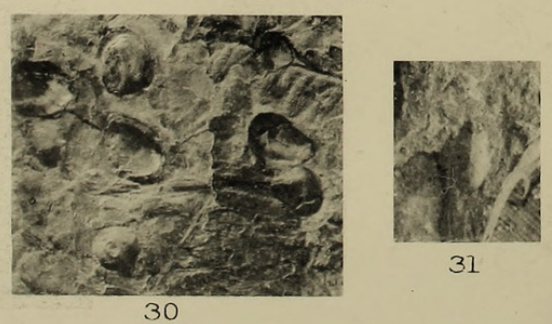

31

EAN A\&WTams Photo

ARBER - SEED IMPRESSIONS
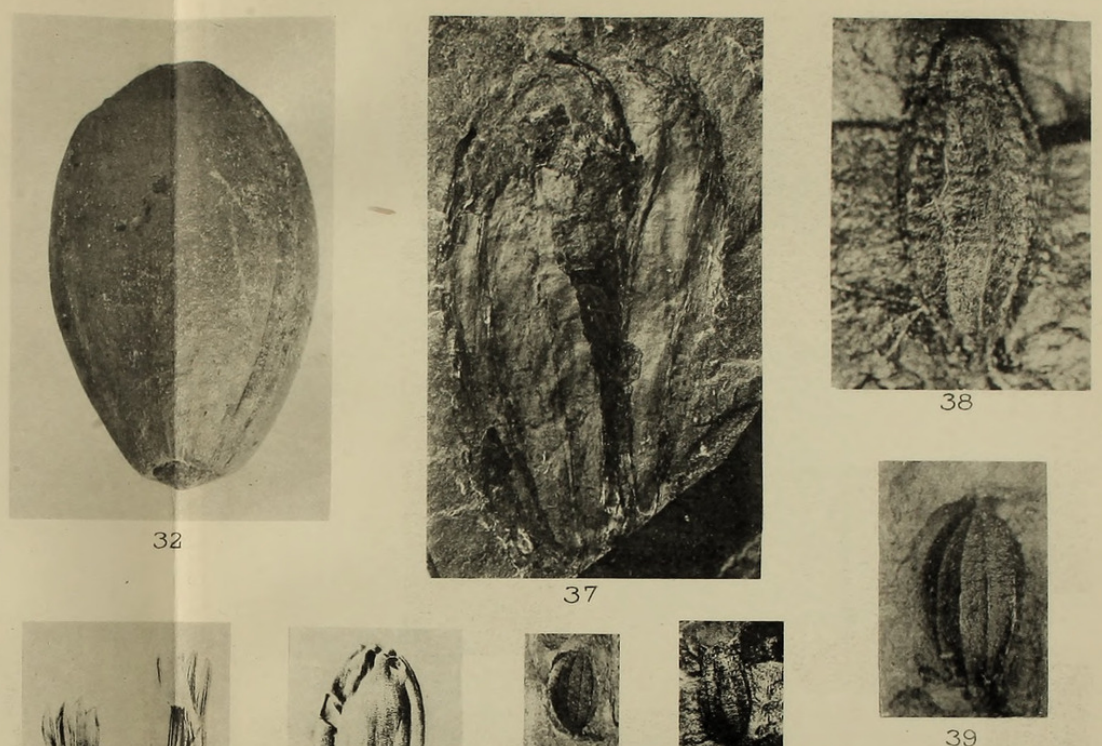

39

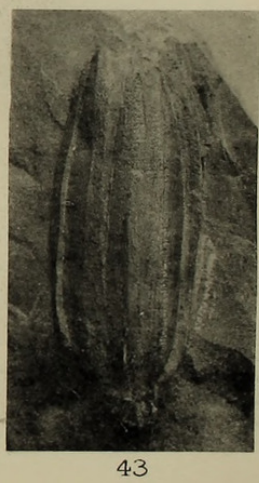

Hoth call. 
Annals of Botany

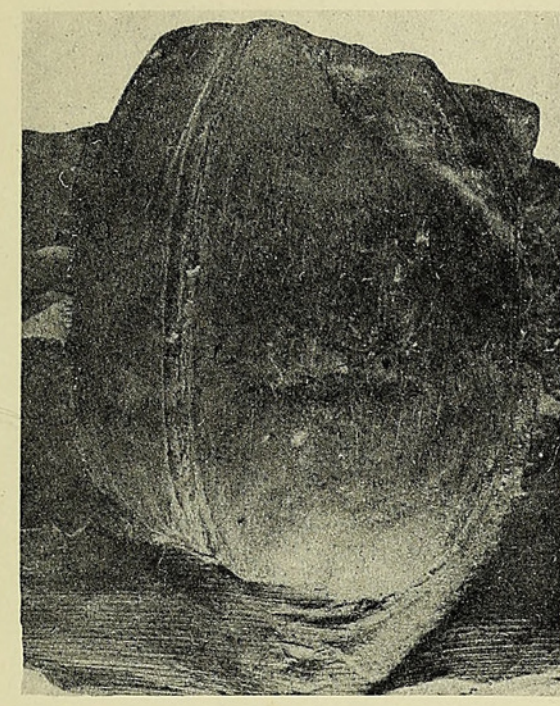

44

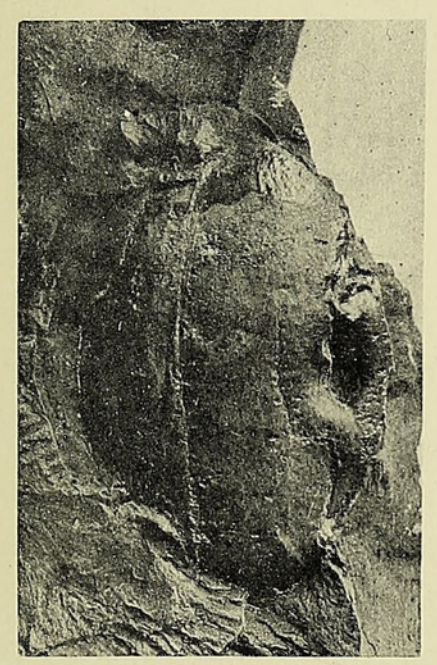

45

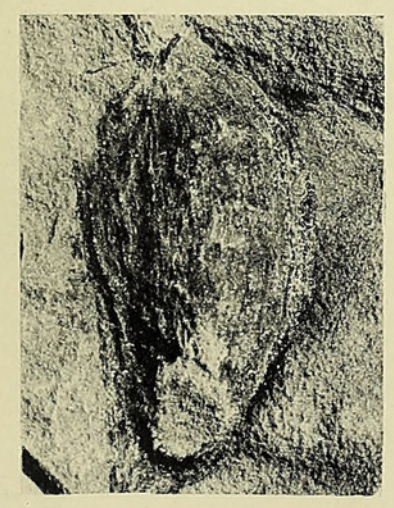

47

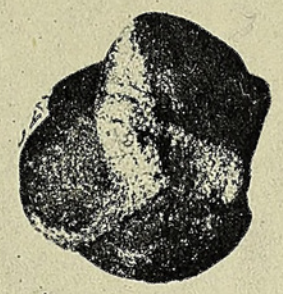

49

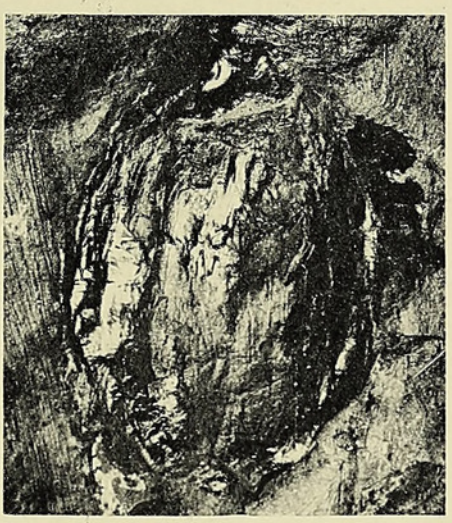

46

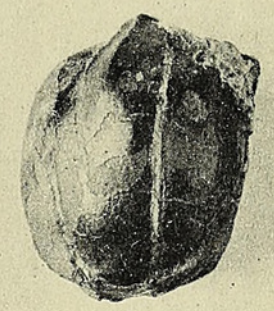

48

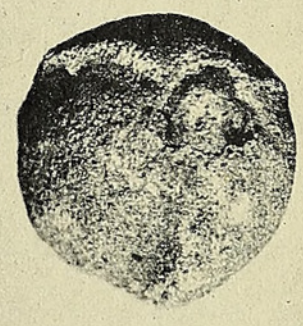

50

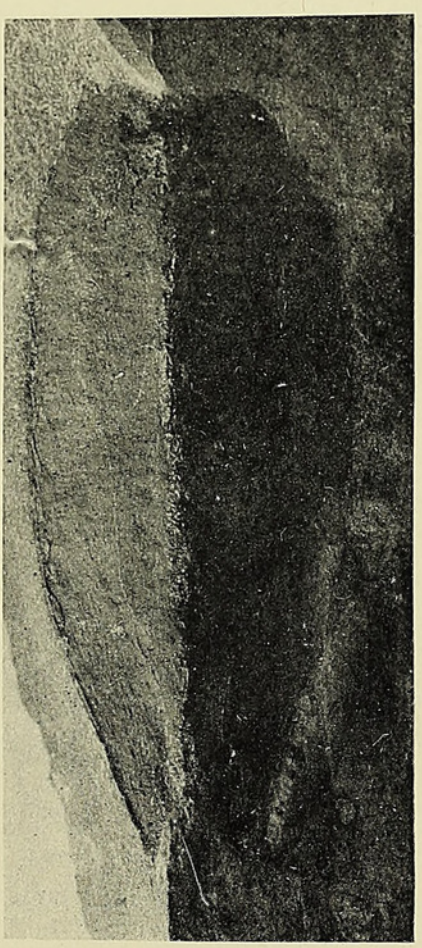

51

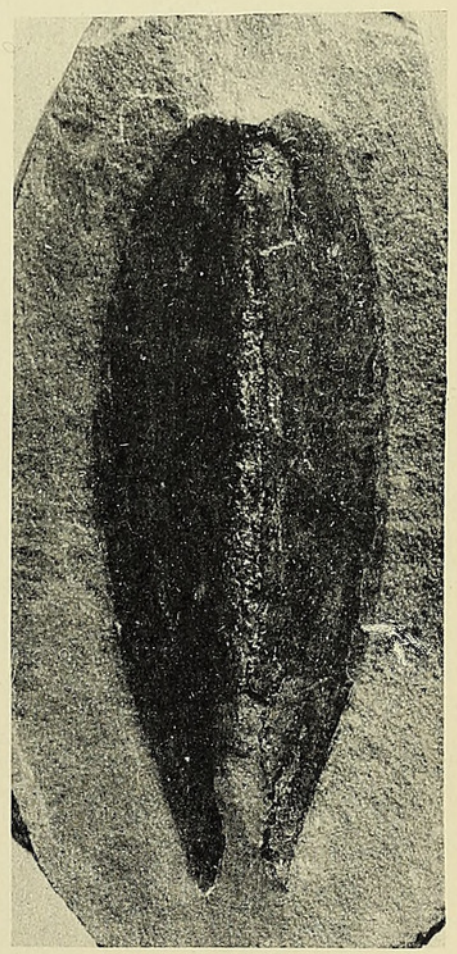

52

W.Tams.photo

ARBER - SEED IMPRESSIONS.

Huth. coll. 


\section{$2 \mathrm{BHL}$ Biodiversity Heritage Library}

Arber, E. A. Newell. 1914. "A revision of the seed impressions of the british coal measures." Annals of botany 28, 81-108.

https://doi.org/10.1093/oxfordjournals.aob.a089498.

View This Item Online: https://www.biodiversitylibrary.org/item/236856

DOI: https://doi.org/10.1093/oxfordjournals.aob.a089498

Permalink: https://www.biodiversitylibrary.org/partpdf/320010

\section{Holding Institution}

Smithsonian Libraries

\section{Sponsored by}

Biodiversity Heritage Library

\section{Copyright \& Reuse}

Copyright Status: Not in copyright. The BHL knows of no copyright restrictions on this item.

This document was created from content at the Biodiversity Heritage Library, the world's largest open access digital library for biodiversity literature and archives. Visit BHL at https://www.biodiversitylibrary.org. 